\title{
Towards mastering CRISPR-induced gene knock-in in plants: Survey of key features and focus on the model Physcomitrella patens
}

\author{
Cécile Collonnier ${ }^{*, 1}$, Anouchka Guyon-Debast ${ }^{1}$, François Maclot, Kostlend Mara, Florence Charlot, \\ Fabien Nogué ${ }^{*}$
}

INRA Centre de Versailles-Grignon, IJPB (UMR1318) - route de St-Cyr, 78026 Versailles cedex, France

\section{A R T I C L E I N F O}

\section{Article history:}

Received 9 January 2017

Received in revised form 10 April 2017

Accepted 21 April 2017

Available online 4 May 2017

\section{Keywords:}

CRISPR-Cas9 system

Gene knock-in

Genome editing

Gene targeting

Physcomitrella patens

\begin{abstract}
A B S T R A C T
Beyond its predominant role in human and animal therapy, the CRISPR-Cas9 system has also become an essential tool for plant research and plant breeding. Agronomic applications rely on the mastery of gene inactivation and gene modification. However, if the knock-out of genes by non-homologous end-joining (NHEJ)-mediated repair of the targeted double-strand breaks (DSBs) induced by the CRISPR-Cas9 system is rather well mastered, the knock-in of genes by homology-driven repair or end-joining remains difficult to perform efficiently in higher plants. In this review, we describe the different approaches that can be tested to improve the efficiency of CRISPR-induced gene modification in plants, which include the use of optimal transformation and regeneration protocols, the design of appropriate guide RNAs and donor templates and the choice of nucleases and means of delivery. We also present what can be done to orient DNA repair pathways in the target cells, and we show how the moss Physcomitrella patens can be used as a model plant to better understand what DNA repair mechanisms are involved, and how this knowledge could eventually be used to define more performant strategies of CRISPR-induced gene knock-in.
\end{abstract}

(c) 2017 Elsevier Inc. All rights reserved.

\section{Contents}

1. Optimizing gene knock-in: A prerequisite to many applications of the CRISPR-Cas system in plant research and breeding. ......... 104

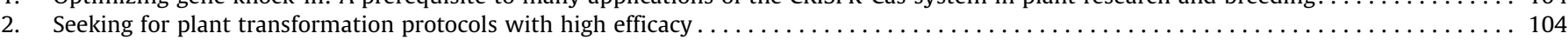

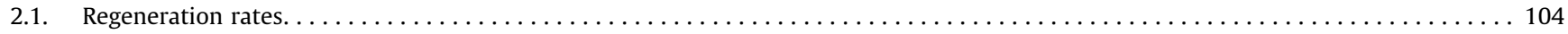

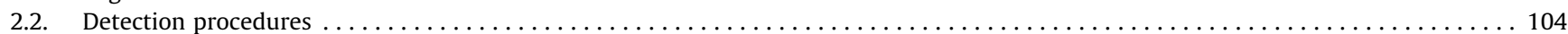

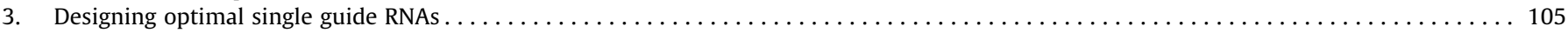

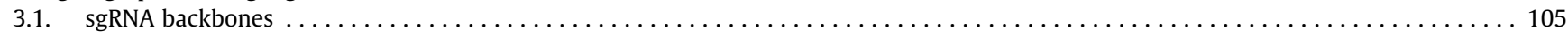

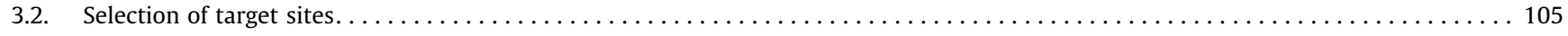

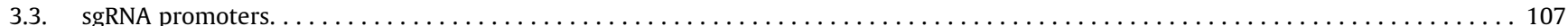

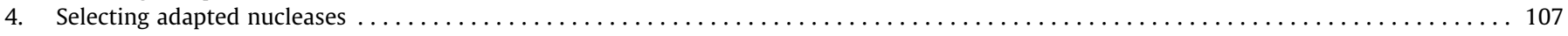

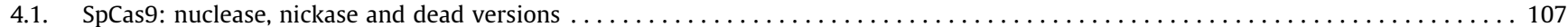

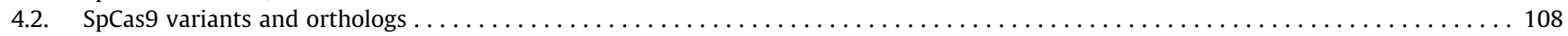

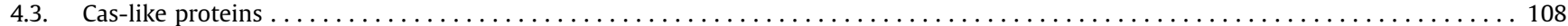

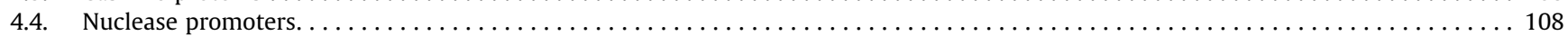

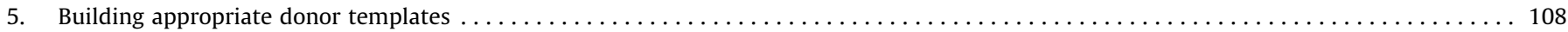

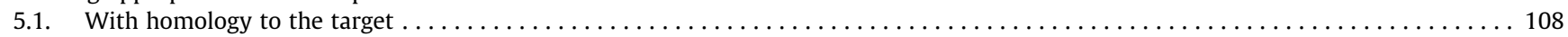

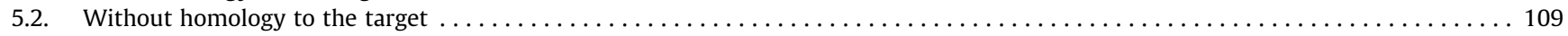

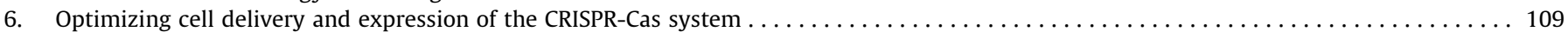

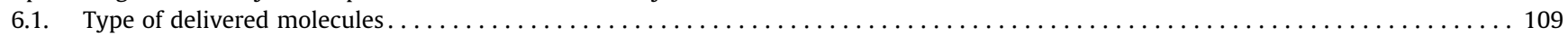

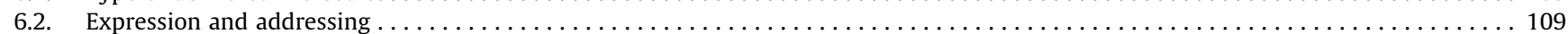

\footnotetext{
* Corresponding authors.

E-mail addresses: cecile.collonnier@inra.fr (C. Collonnier), fabien.nogue@inra.fr (F. Nogué).

${ }^{1}$ These authors contributed equally to this work.
} 


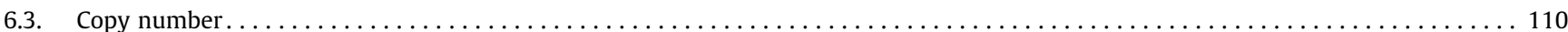

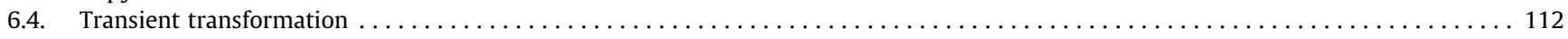

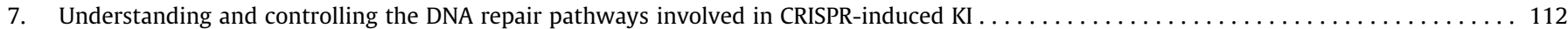

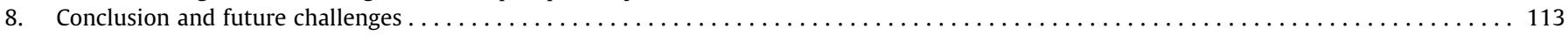

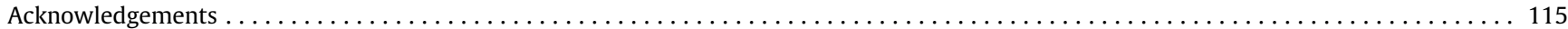

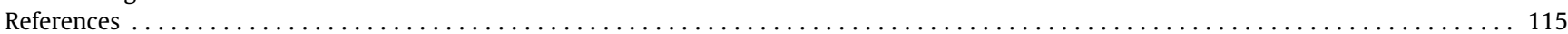

\section{Optimizing gene knock-in: A prerequisite to many applications of the CRISPR-Cas system in plant research and breeding}

The new potentialities of plant genome editing offered by the CRISPR-Cas9 system make it a very interesting tool for plant research and breeding. Genomic modifications can be obtained either by repairing the induced double-strand breaks (DSB) by error-prone end joining, such as alternative non-homologous end joining (NHEJ-alt) that will generate mutations (gene knock-out), or by end joining or homologous recombination of an exogenous donor DNA (gene knock-in) leading to allele replacement or targeted transgene insertion [1-3]. The system can also be used to trigger targeted chromosomal rearrangements potentially useful to increase mapping resolution of specific traits [4] or to regulate gene expression by using the catalytically inactivated Cas9 (dCas9) fused to various effector domains [5]. Through these different approaches, the CRISPR-Cas9 system can very efficiently serve the deciphering of biological mechanisms and the identification and validation of candidate genes. However, some of these techniques are still in their early developments in plants, and gene knock-in, in particular, needs to be optimized for many species. Indeed, whereas the knock-out of endogenous plant loci is generally easy to achieve (with mutagenesis efficiencies varying from $2 \%$ [6] to $100 \%$ [7] of mutated individuals), CRISPR-induced gene knock-in of a donor DNA by homology-driven repair (HDR) is much more difficult to perform in higher plants, with efficiencies rarely reaching a few percent [2,6,8-11]. It explains why among the CRISPR-induced traits already reported in the literature, such as diseases tolerances [12-14], adaptation to drought [2], modified ripening profiles [15], male sterility and factors impacting yield $[9,16,17]$, most of them are derived from gene knock-out, and still very few from gene knock-in. Yet, many potential applications of the CRISPR-Cas9 system to plant breeding require the insertion of alleles of interest into elite lines and rely on the development of gene knock-in protocols with good efficiency. In particular, CRISPR-assisted gene modification could play a critical role in variety innovation (i) to simplify and accelerate selection schemes, (ii) to support the creation of a new genetic variability and the exploitation of genetic resources, and (iii) to achieve specific breeding goals that could not be reached easily without it (e.g. breaking linkage drags, modifying gene families). Therefore, finding means of undoing the technological locks curbing the success rate of CRISPR-mediated gene knock-in is essential for its full use by the academic and private sectors of the seed chain. The following chapters present the different strategies that can be explored to reach this goal.

\section{Seeking for plant transformation protocols with high efficacy}

The CRISPR-Cas9 system has been successfully applied to an increasing range of model and crop species $[7,18,19]$. However, it is still limited to plants for which efficient transformation and regeneration protocols are available. These protocols have been developed for many plant species, but they are very often still restricted to certain genotypes, usually selected for their competency to in vitro culture. They need to be optimized, first to allow transformation of larger ranges of varieties including elite lines, but also because regeneration is very often a bottleneck that reduces the overall CRISPR editing efficiency.

\subsection{Regeneration rates}

In addition to the classical in vitro approaches based on the systematic testing of modified physical or physiological parameters and on the use of chemical enhancers of regeneration (via organogenesis or embryogenesis) [20], insertion into the genome of growth-stimulating transgenes can also be explored. Recently, maize inbred lines that were recalcitrant to transformation could be transformed with $40 \%$ efficiency by overexpressing the maize $B A B Y$ BOOM (BBM) and WUSCHEL2 (WUS2) genes [21]. This system allows drastic increases in regeneration rates from various types of tissues and organs (such as leaves, calli and protoplasts), which makes it adapted to different transformation protocols (personal comm.). High transformation frequencies could be obtained using the same strategy in other monocot species including sorghum, sugarcane and rice [21]. Overexpression of Phosphomannose isomerase (PMI) and Ovule development protein2 (ODP2) also stimulated transformation and regeneration in maize [6]. Ectopic expression of certain transcription factors, such as WIND1 in Brassica napus, could also enhance the acquisition of regeneration competency [22].

Moreover, high throughput transformation methods can sometimes compensate low efficiency. For example, the labour and space-consuming production of immature embryos necessary for maize classical transformation could be replaced by alternative target tissues, like embryo slices from mature seed or leaf segments from seedlings whose preparation can be automated [21]. To overcome the constraints of plant regeneration (complexity and duration of the protocols, exposure to somaclonal variation), in planta transformation methods, independent from in vitro culture, are also being developed using whole plants or seeds [2325]. However, these technologies are still restricted to very few plant species.

\subsection{Detection procedures}

The timing of detection of the edited individuals is a critical factor. In plants, in case of stable transformation, the CRISPR-Cas system can complete genome editing in early developmental phases and generate T1 transgenic plants showing the expected mutant phenotypes, but it can also be active in later generations. It can thus be interesting to screen $\mathrm{T} 2$ and $\mathrm{T} 3$ progenies to detect newly formed edition events [26]. The sensitivity of the detection can also benefit from enrichment steps, such as the digestion of genomic DNA by restriction enzymes whose sites are located in the cleavage area. The presence of these sites is a parameter that can be taken into account when selecting the sgRNAs. Knock-in events presenting disrupted restriction sites will resist to the digestion and be available for a much more efficient and detectable amplification 
[11]. Furthermore, positive and/or negative selection markers, as well as a high selection pressure for gene modifications during the regeneration process (when the desired phenotype is amenable to it), can be used to increase the probability to see knock-in events [27-29]. For example, potato lines with edited ALS1 gene were easily detected on media containing the herbicide corresponding to the tolerance conferred by the knock-in of the modified allele [27]. For transient transformation protocols on protoplasts, a preselection of the transfected cells can be done based on resistance genes inserted in the plasmid bearing the CRISPR system and the donor template. The cells resisting transiently to the corresponding selective pressure will give birth to plants with a higher chance of bearing the desired gene modification. Spectacular increases (up to 10-fold) in CRISPR-induced gene knock-out efficiency were observed in tomato and potato by using this approach (data not shown). Another strategy could consist in using, in addition to the sgRNA(s) specific to the target, a sgRNA targeting an endogenous gene whose mutation leads to an early and easy selectable phenotype, such as GLABROUS1 (GL1) required for the formation of trichomes in Arabidopsis thaliana [30], the idea being that in the seedlings presenting the phenotype, the CRISPR-Cas system was activated and may have also cleaved the target and led to the desired gene knock-in events.

\section{Designing optimal single guide RNAs}

To successfully perform gene knock-in mediated by the CRISPRCas system, the first critical step is to be able to specifically cleave the target site. For that matter, just like for gene knock-out, designing optimal guide RNAs and expressing them efficiently is essential.

\section{1. sgRNA backbones}

In the CRISPR-Cas systems adapted to eukaryotes, the Cas9 nuclease is often guided to its target by a single guide RNA (sgRNA) replacing the bacterial dual guide RNA formed by the association of a crRNA and a tracRNA [31]. Depending on the species of origin, the structure of the sgRNAs can be optimized for better expression and activity [32]. For example, for sgRNAs derived from Streptococcus pyogenes ( $\mathrm{Sp}$ ), the length of the upper stem mimicking the bacterial crRNA/tracRNA duplex can be increased for better stability, and the thymine repeat of the lower stem can be decreased for improved transcription [33]. On the opposite, for S. aureus, lengthening the upper stem has to be avoided since it seems to reduce efficiency [32]. For Cpf1 (a new class 2 CRISPR nuclease, see chapter 4), the structure of the crRNA guiding it to the target can also be improved. For instance, with Cpf1 from Lachnospiraceae bacterium (Lb), pre-crRNAs with a full length direct repeat sequence, or with two full length direct repeat sequences framing the spacer, appeared more efficient than mature crRNAs [34].

\subsection{Selection of target sites}

For the Cas9 to be able to cleave DNA, the protospacer of the sgRNA (corresponding to the $20 \mathrm{bp}$ of the target) has to hybridize next to a protospacer-adjacent motif (PAM) composed of a few specific nucleotides (e.g. NGG for the native Cas9 from Streptococcus pyogenes) [31]. The recognition of the PAM participates to the triggering of the conformational change of the nuclease that is necessary for the right positioning of the two catalytic sites on both DNA strands of the target [35]. The presence of a PAM is basically the principal requirement for the design of a sgRNA. Publically available on-line interfaces have been developed to identify in a given sequence all the potential target sites located near PAMs on both strands of the genomic DNA [36,37]. For the knock-out of a gene, it is recommended to choose a cleavage site in an exon, close to the start codon (or downstream of the last ATG codon in frame to make sure no functional mRNAs will be produced) and with a high probability of leading to a frameshift (out-of-frame score). For gene knock-in, there are no such restrictions and the target can be located in any genetic elements located next to a PAM.

For each potential sgRNA, the design tools often identify in the reference genome of the studied species all the possible off-target sites, meaning sequences located next to a PAM and homologous to the target except for a few base pairs (usually up to 4, the risk of undesired editing being considered very low with 5 and more mismatches). The number of these sites and the number and position of their mismatches with the target are used to establish a specificity score. High specificity scores (95-100\%) are required to limit undesired off-target editing. SgRNAs presenting the least possible number of off-target sites with the highest possible number of mismatches, if possible located in the seed sequence (the $12 \mathrm{bp}$ directly upstream the PAM where mismatches can eliminate nuclease activity) are preferable. The position of each off-target site on the reference genome should be checked to make sure to avoid the knock-down of key sequences (lethal genes, genes potentially involved in the desired phenotype, ...). A priori, the analysis of sgRNAs' specificity is limited to plants for which reference genomes are available, but certain platforms offer access to free versions of their algorithms that can be run on individual computers for still unpublished reference genomes (e.g. crispor.tefor.net). Additionally for gene knock-in experiments, the presence of offtargets sites needs to be checked also on the donor template molecule to avoid it being cleaved before or after the targeted insertion.

Taking into account certain DNA structural features, some bioinformatics models also propose to predict the editing efficiency of sgRNAs [32,38]. However, these efficiency scores are mostly calculated from formulas developed based on experimental data obtained on animal model organisms and their applicability to plants remains purely theoretical. Therefore, they are not always a guaranty of success and should be used as additional information to help select between sgRNAs identically interesting otherwise.

Another criterion of choice for sgRNAs can be the composition of the last base pairs (bp) of the protospacer. For instance, a highest cleavage efficiency was observed in C. elegans when the final $6 \mathrm{bp}$ of the protospacers of Sp-derived sgRNAs contained 4 or more GCs [39]. Identically, a better frequency of cleavage and homology-driven gene knock-in was demonstrated in C. elegans with protospacers ending with a GG motif [40]. This could be due to the fact that a high proportion of GCs close to the PAM would make the Cas9 stay longer on the target and give it more chance of cutting.

Finally, it was demonstrated in Physcomitrella patens that a strong bias towards MMEJ (microhomology end-joining)-driven targeted mutagenesis was observed when inducing DSBs in the vicinity of sequences presenting microhomologies [41]. To avoid this phenomenon that could compete with the insertion of the donor template, selecting sgRNAs inducing DSBs at sites that do not present obvious microhomologies of more than $2 \mathrm{bp}$ in the vicinity of the cleavage site (usually occuring $3 \mathrm{bp}$ upstream the PAM) is preferable.

Using pairs of sgRNAs targeting two sites in the same locus is also a way to increase the probability of inducing genomic deletions [33], which could stimulate replacement of the target by the donor DNA. It was used very efficiently for gene replacement in rice by inducing two cuts in the introns framing the exon to replace [3]. 


\begin{tabular}{|c|c|c|c|c|c|c|c|c|}
\hline Species & Target & $\begin{array}{l}\text { Transformation } \\
\text { method }\end{array}$ & Type of Cas & $\begin{array}{l}\text { Promoters } \\
\text { (Cas9, sgRNA) }\end{array}$ & Cloning strategy & Donor template & $\begin{array}{l}\text { KI frequency (by HR } \\
\text { or IR) }\end{array}$ & Reference \\
\hline $\begin{array}{r}\text { Arabidopsis } \\
\text { thaliana }\end{array}$ & AtADH1 & $\begin{array}{l}\text { Agrobacterium } \\
\text { (floral dip) }\end{array}$ & $\begin{array}{l}\text { SpCas9 } \\
\text { codon-opt for } \\
\text { Arabidopsis }\end{array}$ & $\begin{array}{l}\text { PcUBI4-2, } \\
\text { AtU6 }\end{array}$ & $\begin{array}{l}\text { Cas9 + sgRNA + donor template on one single } \\
\text { plasmid }\end{array}$ & $\begin{array}{l}\text { In planta released dsDNA, } 1.8 \mathrm{~kb}+674 \\
\text { and } 673 \mathrm{bp} \text { homology arms }\end{array}$ & $0.14 \%$ & $\begin{array}{l}\text { Schiml } \\
\text { et al. } \\
\text { (2014) }\end{array}$ \\
\hline $\begin{array}{l}\text { Nicothiana } \\
\text { benthamiana }\end{array}$ & NbPDS & $\begin{array}{l}\text { Transient, PEG- } \\
\text { on protoplast }\end{array}$ & $\begin{array}{l}\text { SpCas9 } \\
\text { codon-opt for } \\
\text { Arabidopsis }\end{array}$ & $\begin{array}{l}\text { CaMV35SPDK, } \\
\text { AtU6 }\end{array}$ & $\begin{array}{l}\text { Cas9 + sgRNA on one plasmid, donor template on a } \\
\text { second plasmid }\end{array}$ & $\begin{array}{l}\text { Circular dsDNA, } 6 \text { bp }+533 \text { and } 114 \text { bp } \\
\text { homology arms }\end{array}$ & $10.7 \%$ & $\begin{array}{l}\text { Li et al. } \\
\text { (2013) }\end{array}$ \\
\hline $\begin{array}{l}\text { Lycopersicon } \\
\text { esculentum }\end{array}$ & SLANT1 & $\begin{array}{l}\text { Agrobacterium } \\
\text { (infiltration } \\
\text { cotyledons) }\end{array}$ & $\begin{array}{l}\text { SpCas9 } \\
\text { codon-opt for } \\
\text { Arabidopsis }\end{array}$ & $\begin{array}{l}\text { CaMV35S, } \\
\text { AtU6 }\end{array}$ & $\begin{array}{l}\text { Cas9 + sgRNA + donor template in one BeYDV } \\
\text { replicon }\end{array}$ & $\begin{array}{l}\text { Circular dsDNA, } 1.9 \mathrm{~kb}+987 \mathrm{bp} \text { and } \\
719 \mathrm{bp} \text { homology arms }\end{array}$ & $3.65-11.66 \%$ & $\begin{array}{l}\text { Cermak } \\
\text { et al. } \\
\text { (2015) }\end{array}$ \\
\hline $\begin{array}{l}\text { Solanum } \\
\text { tuberosum }\end{array}$ & StALS1 & $\begin{array}{l}\text { Agrobacterium } \\
\text { (co-culture, } \\
\text { leaves) }\end{array}$ & $\begin{array}{l}\text { SpCas9 } \\
\text { codon-opt for } \\
\text { Arabidopsis }\end{array}$ & $\begin{array}{l}\text { CaMV35S, } \\
\text { AtU6 }\end{array}$ & $\begin{array}{l}\text { Cas9 + sgRNA + donor template + LIR-SIR from } \\
\text { BeYDV on one plasmid, transformed into plants } \\
\text { expressing Rep constitutively }\end{array}$ & $\begin{array}{l}\text { Circular dsDNA, } 369 \mathrm{bp}+1.6 \mathrm{~kb} \text { and } \\
1 \mathrm{~kb} \text { homology arms }\end{array}$ & $12.5 \%(1 / 8$ lines $)$ & $\begin{array}{l}\text { Butler } \\
\text { et al. } \\
\text { (2016) }\end{array}$ \\
\hline \multirow[t]{3}{*}{$\begin{array}{l}\text { Triticum } \\
\quad \text { aestivum }\end{array}$} & $\begin{array}{l}\text { TaMLO, } \\
\text { TaUBI }\end{array}$ & $\begin{array}{l}\text { Bombardment } \\
\text { of immature } \\
\text { embryos }\end{array}$ & $\begin{array}{l}\text { SpCas9 } \\
\text { codon-opt for } \\
\text { wheat }\end{array}$ & ZmUBI1, TaU6 & $\begin{array}{l}\text { Cas9 + } 1 \text { sgRNA + donor template in one WDV } \\
\text { replicon }\end{array}$ & $\begin{array}{l}\text { Circular dsDNA, } 1.5 \mathrm{~kb}+747-773 \mathrm{bp} \text { or } \\
1 \mathrm{~kb}+674-647 \mathrm{bp} \mathrm{homology} \text { arms }\end{array}$ & 5.74 and $6.4 \%$ & \multirow{3}{*}{$\begin{array}{l}\text { Gil- } \\
\text { Humanes } \\
\text { et al. } \\
(2016)\end{array}$} \\
\hline & $\begin{array}{l}\text { TaMLO, } \\
\text { TaUBI }\end{array}$ & $\begin{array}{l}\text { Bombardment } \\
\text { of immature } \\
\text { embryos }\end{array}$ & $\begin{array}{l}\text { SpCas9 } \\
\text { codon-opt for } \\
\text { wheat }\end{array}$ & ZmUBI1, TaU6 & $\begin{array}{l}2 \mathrm{x}[\text { Cas9 + } 1 \text { sgRNA + donor template in one WDV } \\
\text { replicon] }\end{array}$ & $\begin{array}{l}\text { Circular dsDNA, } 1.5 \mathrm{~kb}+747-773 \text { bp or } \\
1 \mathrm{~kb}+674-647 \text { bp homology arms }\end{array}$ & $\begin{array}{l}3.25-5.85 \% \text { for single } \\
\text { KI, } 1.1 \% \text { for double KI }\end{array}$ & \\
\hline & $\begin{array}{l}\text { TaUBI, } \\
\text { TaEPSPS }\end{array}$ & $\begin{array}{l}\text { Bombardment } \\
\text { of immature } \\
\text { embryos }\end{array}$ & $\begin{array}{l}\text { SpCas9 } \\
\text { codon-opt for } \\
\text { wheat }\end{array}$ & ZmUBI1, TaU6 & $\begin{array}{l}\text { Cas9 + } 2 \text { sgRNAs + } 2 \text { donor templates in one WDV } \\
\text { replicon }\end{array}$ & $\begin{array}{l}\text { Circular dsDNA, } 1.8 \mathrm{~kb}+210-747 \mathrm{bp} \\
\text { and } 646-773 \text { bp homology arms }\end{array}$ & $\begin{array}{l}\text { Single and double KI } \\
\text { detected, freq not } \\
\text { given }\end{array}$ & \\
\hline Oryza sativa & OsPDS & $\begin{array}{l}\text { Transient, PEG } \\
\text { on protoplasts }\end{array}$ & $\begin{array}{l}\text { SpCas9 } \\
\text { codon-opt for } \\
\text { rice }\end{array}$ & $\begin{array}{l}\text { 2xCaMV35S, } \\
\text { OsU3 }\end{array}$ & Cas9 and sgRNA on 2 separate plasmids & $\begin{array}{l}\text { ssDNA fragment, } 12 \mathrm{bp}+60 \mathrm{bp} \\
\text { homology }\end{array}$ & $7 \%$ & $\begin{array}{l}\text { Shan et al. } \\
\text { (2013) }\end{array}$ \\
\hline \multirow[t]{2}{*}{ Oryza sativa } & \multirow[t]{2}{*}{ OSEPSPS } & \multirow[t]{2}{*}{$\begin{array}{l}\text { Agrobacterium } \\
\text { (embryonic } \\
\text { cells) }\end{array}$} & \multirow[t]{2}{*}{$\begin{array}{l}\text { SpCas9 } \\
\text { codon-opt for } \\
\text { maize }\end{array}$} & \multirow[t]{2}{*}{$\begin{array}{l}\text { 2xCaMV35S, } \\
\text { OsU3 and } \\
\text { TaU3 }\end{array}$} & $\begin{array}{l}\text { Cas9 + } 2 \text { sgRNAs on one plasmid, donor template on a } \\
\text { second plasmid }\end{array}$ & $\begin{array}{l}\text { In planta released dsDNA fragment of } \\
442 \mathrm{bp} \text {, homologous to the target with } \\
3 \text { substitutions }\end{array}$ & $2 \%$ & \multirow[t]{2}{*}{$\begin{array}{l}\text { Li et al. } \\
\text { (2016) }\end{array}$} \\
\hline & & & & & $\begin{array}{l}\text { Cas } 9+1 \text { sgRNA on one plasmid, donor template on a } \\
\text { second plasmid }\end{array}$ & $\begin{array}{l}\text { In planta released dsDNA fragment of } \\
1.6 \mathrm{~kb} \text {, no homology arms }\end{array}$ & $2.2 \%$ & \\
\hline \multirow[t]{3}{*}{ Oryza sativa } & \multirow[t]{3}{*}{ OsALS } & \multirow{2}{*}{$\begin{array}{l}\text { Bombardment } \\
\text { of embryonic } \\
\text { calli }\end{array}$} & \multirow{2}{*}{$\begin{array}{l}\text { SpCas9 } \\
\text { codon-opt for } \\
\text { maize }\end{array}$} & \multirow[t]{2}{*}{ ZmUBI, OsU3 } & $\begin{array}{l}\text { Cas9 + sgRNA on one plasmid, donor template as a } \\
\text { ssDNA fragment }\end{array}$ & $\begin{array}{l}\text { ssDNA fragment, } 330 \mathrm{bp}+100 \mathrm{bp} \text { and } \\
46 \mathrm{bp} \text { homology arms }\end{array}$ & $0 \%$ & \multirow[t]{3}{*}{$\begin{array}{l}\text { Sun et al. } \\
(2016)\end{array}$} \\
\hline & & & & & $\begin{array}{l}\text { Cas9 + } 2 \text { sgRNAs + donor template on one plasmid, } \\
\text { additional donor template as dsDNA fragment }\end{array}$ & $\begin{array}{l}\text { In planta released and free dsDNA } \\
\text { fragments, } 330 \mathrm{bp}+100 \mathrm{bp} \text { and } 46 \mathrm{bp} \\
\text { homology arms }\end{array}$ & $\begin{array}{l}36 \% \text { (with pre- } \\
\text { selection, } 116 \text { lines/ } \\
320 \text { calli) }\end{array}$ & \\
\hline & & $\begin{array}{l}\text { Agrobacterium } \\
\text { (embryonic } \\
\text { cells) }\end{array}$ & $\begin{array}{l}\text { SpCas9 } \\
\text { codon-opt for } \\
\text { maize }\end{array}$ & ZmUBI, OsU3 & Cas9 + 2 sgRNAs + donor template on one plasmid & $\begin{array}{l}\text { In planta released dsDNA fragment, } \\
330 \mathrm{bp}+100 \mathrm{bp} \text { and } 46 \text { bp homology } \\
\text { arms }\end{array}$ & $\begin{array}{l}25 \% \text { (with pre- } \\
\text { selection, } 75 \% \text { of } 80 \\
\text { lines } / 240 \text { calli) }\end{array}$ & \\
\hline \multirow[t]{5}{*}{ Zea mays } & \multirow[t]{2}{*}{ ZmALS2 } & \multirow{2}{*}{$\begin{array}{l}\text { Bombardment } \\
\text { of immature } \\
\text { embryos }\end{array}$} & \multirow{2}{*}{$\begin{array}{l}\text { SpCas9 } \\
\text { codon-opt for } \\
\text { maize }\end{array}$} & \multirow[t]{2}{*}{$\begin{array}{l}\text { ZmUBI1, } \\
\text { ZmU6 }\end{array}$} & Cas9, sgRNA, donor template on 3 separate plasmids & $\begin{array}{l}\text { Circular ds DNA, } 794 \text { bp homologous to } \\
\text { the target except for } 2 \text { substitutions }\end{array}$ & $0.2 \%$ & \multirow{5}{*}{$\begin{array}{l}\text { Svitashev } \\
\text { et al. } \\
\text { (2015) }\end{array}$} \\
\hline & & & & & Cas9, sgRNA on 2 separate plasmids & $\begin{array}{l}\text { ssDNA fragment, } 127 \text { bp homologous } \\
\text { to the target except for } 4 \text { or } 7 \\
\text { substitutions }\end{array}$ & $0.3-0.4 \%$ & \\
\hline & \multirow[t]{3}{*}{$Z m L I G$} & \multirow{2}{*}{$\begin{array}{l}\text { Bombardment } \\
\text { of immature } \\
\text { embryos }\end{array}$} & \multirow{2}{*}{$\begin{array}{l}\text { SpCas9 } \\
\text { codon-opt for } \\
\text { maize }\end{array}$} & \multirow[t]{2}{*}{$\begin{array}{l}\text { ZmUBI1, } \\
\text { ZmU6 }\end{array}$} & Cas9, sgRNA, donor template on 3 separate plasmids & $\begin{array}{l}\text { Circular dsDNA, } 3.1 \mathrm{~kb}+1 \mathrm{~kb} \text { and } 1 \mathrm{~kb} \\
\text { homology arms }\end{array}$ & $2.5 \%$ & \\
\hline & & & & & Cas9, sgRNA, donor template on a single plasmid & $\begin{array}{l}\text { Circular dsDNA, } 3.1 \mathrm{~kb}+1 \mathrm{~kb} \text { and } 1 \mathrm{~kb} \\
\text { homology arms }\end{array}$ & $4.1 \%$ & \\
\hline & & $\begin{array}{l}\text { Agrobacterium } \\
\text { (embryonic } \\
\text { cells) }\end{array}$ & $\begin{array}{l}\text { SpCas9 } \\
\text { codon-opt for } \\
\text { maize }\end{array}$ & $\begin{array}{l}\text { ZmUBI1, } \\
\text { ZmU6 }\end{array}$ & Cas9, sgRNA, donor template on a single plasmid & $\begin{array}{l}\mathrm{dsDNA}, 3.1 \mathrm{~kb}+1 \mathrm{~kb} \text { and } 1 \mathrm{~kb} \\
\text { homology arms }\end{array}$ & $0 \%$ & \\
\hline Zea mays & ZmALS2 & $\begin{array}{l}\text { Bombardment } \\
\text { of immature } \\
\text { embryos }\end{array}$ & $\begin{array}{l}\text { SpCas9 } \\
\text { codon-opt for } \\
\text { maize }\end{array}$ & $\begin{array}{l}\text { ZmUBI1, } \\
\text { ZmU6 }\end{array}$ & $\begin{array}{l}\text { Cas9 protein associated to in vitro transcribed } \\
\text { sgRNAs }\end{array}$ & $\begin{array}{l}\text { ssDNA fragment, } 127 \mathrm{bp} \text { homologous } \\
\text { to the target except for } 7 \text { substitutions }\end{array}$ & $2-2.5 \%$ & $\begin{array}{l}\text { Svitashev } \\
\text { et al. } \\
\text { (2016) }\end{array}$ \\
\hline
\end{tabular}




\section{3. sgRNA promoters}

As non-coding RNAs, sgRNAs are usually put under the control of promoters recognized by the Polymerase III (that synthesizes the majority of non-coding RNA molecules in eukaryotic cells and as such does not add any final polyadenylation signal to the RNA it transcribes). For that reason, it is important to check that the sgRNAs sequences do not contain any motif of 4 to 6 Ts in a row which is a signal for the termination of RNA Pol III transcripts. In plants, promoters from the U3 and U6 genes from the studied species or at least from a species of the same type (mono- or dicotyledonous) are used. For an optimal expression, the sgRNA sequence has to start with an A or a $\mathrm{G}$ for the U3 and U6 promoters respectively. This base can be either the first base of the guide or, if it is not the case, can be added in front of the protospacer in the sgRNA backbone. Both U3 and U6 promoters have been successfully used in plants without distinction. When cloning two sgRNAs in the same backbone vector for a simultaneous use, it can be useful to associate one to a U3 promoter and the other to a U6 promoter to limit the formation of hairpin structures and facilitate DNA synthesis and cloning.

\section{Selecting adapted nucleases}

CRISPR-induced gene knock-in relies on an efficient cleavage of the target site. For that matter, optimal guide RNAs have to be associated to appropriate nucleases with good expression levels. Different types of Cas and Cas-like proteins are available. All of them proved their efficiency to cleave targets and trigger mutagenesis, but, for the most part, their impact on gene knock-in remains to be tested.

\subsection{SpCas9: nuclease, nickase and dead versions}

In plants, the gene coding for the Cas9 protein from Streptococcus pyogenes (SpCas9) was codon-optimized for a good expression either in monocotyledonous or in dicotyledonous species [42,43]. The SpCas9 nuclease is the only Cas to have been used so far to induce gene knock-in in higher plants with efficiencies varying from 0.14 to $36 \%$ depending on the species, the delivery strategy and the transformation protocol (see Table 1). Up to now, it is the nuclease of choice for gene knock-in experiments, but other types of proteins are also promising.

SpCas9 nickases, in which one of its catalytic domains has been mutated [31], can be used in pairs to induce two single-strand breaks (SSBs) surrounding the target and to generate knock-in with limited non-homologous end-joining (NHEJ)-induced mutations at the insertion sites. In A. thaliana reporter lines bearing a recombination substrate, HDR occurred at the target site in the same proportions using the nickase $\mathrm{D}^{\mathrm{D} 10 \mathrm{~A}}$ and the nuclease versions of SpCas9 [44]. The ability to trigger efficient gene knock-in in plants using this approach remains to be evaluated. In human cells, Cas9 $9^{\mathrm{D} 10 \mathrm{~A}}$ was shown to be less efficient at inducing reporter gene knock-in than the fully functional Cas9 nuclease [45].

The deadCas9, in which both catalytic domains are mutated, can be fused to a cytidine deaminase enzyme capable of converting $C$ to $\mathrm{T}$ ( or $\mathrm{G}$ to $\mathrm{A}$ ) upstream the PAM in the non-template DNA strand. This system allows to introduce specific point mutations in a target gene without inducing any DSB and involving any DNA template. In that case, allele modification is obtained by targeted base editing, instead of gene knock-in [46]. For better efficiency, the cytidine deaminase can be fused to a nickase that cleaves the non-edited strand and be associated to the uracil glycosylase inhibitor (UGI) that inhibits base-excision repair, to limit indel formation at the cleavage site [46]. This approach was successfully used to edit 
endogenous genes in tomato, rice, maize and wheat with the Cas9 ${ }^{\mathrm{D} 10 \mathrm{~A}}$ at frequencies of up to $43.48 \%$ [47-50], which is so far much more efficient than HDR-mediated gene replacement. However, the base-editing efficiency seems to be dependent on the target sequence and the criteria for the selection of adapted sgRNAs request further investigations [47].

\subsection{SpCas9 variants and orthologs}

To trigger recombination with a donor template, it was shown that sgRNAs should target genomic sequences located as close to the desired knock-in position as possible [32]. Usually, several PAMs for SpCas9 can easily be found around the target, but if it is not the case, engineered SpCas9 and natural or engineered Cas9 from other bacteria (such as Staphyloccoccus aureus (Sa), Francisella novicida (Fn), Neisseria meningitides (Nm) or Streptococcus thermophiles (St)), with different PAMs and locations of the induced DSBs, are now available for use in eukaryotic cells [51]. However, SpCas9 variants were initially designed for applications in mammalian cells and have not yet been tested in plants [38]. Regarding SpCas9 orthologs, StCas9 and SaCas9 have recently been used to trigger mutagenesis in $A$. thaliana with high efficiency and without any cross interference between nucleases and sgRNA from different species [52]. SaCas9 which showed the highest mutation efficiency (90\%) seems to be the most promising for CRISPR-induced gene knock-in.

\subsection{Cas-like proteins}

Among the native CRISPR-Cas systems, a new type of class 2 effectors has been defined to regroup recently identified Cas9like nucleases such as Cpf1, C2c1 and C2c3 [53]. These nucleases have different requirements than Cas9 in terms of PAM and type of guide RNAs, and cleave nucleic acids in a different manner $[54,55]$. These properties could make some of them potentially interesting to improve GT efficiency. Cpf1 in particular is viewed as a promising tool for gene knock-in for two reasons: first, it cleaves away from the seed region which reduces the risk of NHEJ-induced mutations to happen in this critical area which would prevent the nuclease from cutting again until an HDR event has occurred. Second, Cpf1 generates DNA DSBs with overhangs, instead of blunt ends like Cas9, which could favor homologous recombination between the genomic target and the donor template. Cpf1 from Acidaminococcus sp. (AsCpf1) and Lachnospiraceae bacterium (LbCpf1) have been shown to be functional in rice, soybean and tobacco [34,56-58]. In these plants, LbCpf1 mutagenesis efficiency, which seems to be correlated with the target sequence [56], appeared always higher than those of AsCpf1, reaching sometimes $100 \%$ in rice [58]. Efficient targeted mutagenesis (up to $70 \%$ ) could also be obtained in rice and tobacco by using Cpf1 from Francisella novicida (FnCpf1) [59]. The impact of Cpf1 on gene knock-in in plants still needs to be explored, the two best candidates being LbCpf1 and FnCpf1.

Very recently, a completely new DNA-guided genome editing tool, called NgAgo for Natronobacterium gregoryi Argonaute, has been characterized. This endonuclease from the Argonautes family uses $5^{\prime}$-phosphorylated ssDNA fragments of about 24 nucleotides to induce targeted DSBs at $37^{\circ} \mathrm{C}$. No PAM is required, potentially allowing to target any genomic region. Targeted mutagenesis and gene knock-in with good efficiencies comparable to the CRISPRCas9 system was shown in mammalian cells [60]. However, further studies need to be performed to confirm these results and the capacity of this new system to trigger HDR in other organisms including plants.

\subsection{Nuclease promoters}

To guaranty a good level of expression in the whole plant, the selected nucleases' coding sequences are often placed under the control of strong ubiquitous promoters (Table 1), but the localization and timing of their expression can also be modulated by appropriate specific promoters. For example, SpCas9 could be driven by a nodule-specific promoter to effectively edit genes in Lotus japonicus by hairy root transformation [61]. In order to place the donor DNA and the CRISPR-Cas9 system in a context where HR is favored over NHEJ for DSB repair, the expression of the CRISPR elements can also be triggered or increased in the germlines by using cell-specific promoters $[62,63]$. Inducing genome editing in this type of cells also presents the advantage of limiting the generation of chimeric plants and ensuring a good inheritance of the targeted modifications.

\section{Building appropriate donor templates}

DNA insertion can occur at targeted DSBs either by nonhomologous end-joining or by homology-driven repair (HDR) [64]. If the donor DNA, that can be circular (plasmid) or linear single-stranded (ss) or double-stranded (ds) DNA fragments, is flanked by sequences presenting homology to both sides of the genomic cleavage site, the insertion can occur through homologous recombination (HR) with increased precision. However, donor templates without homology to the target can also be used for targeted insertion.

\subsection{With homology to the target}

Depending on the objective pursued, the donor template either includes a sequence of interest framed by homology arms for the insertion of a sequence of interest, or is itself composed of a sequence homologous to the target with a few bases substitutions for gene replacement $[3,6]$. In that latter case, silent mutations need to be introduced in the sequence homologous to the protospacer and/or to the PAM, to avoid any cleavage of the donor template after insertion.

The length of the homology regions may have an impact on gene knock-in efficiency. In human cells, a direct correlation was observed between the efficiency of HDR of CRISPR-induced DSBs and the size of the homology arms of the donor template, better knock-in efficiency being obtained with homology regions of at least $1 \mathrm{~kb}$ [65]. However, in the MMEJ (microhomology-mediated end joining)-mediated method of gene knock-in named PITCh (precise integration into target chromosome), very short fragments (5$25 \mathrm{bp}$ ) homologous to sequences framing the target are used to trigger the insertion of the donor template via MMEJ and not HR [66].

So far, reports about CRISPR-assisted knock-in experiments in plants describe circular donor templates ranging from 0.47 to $5.2 \mathrm{~kb}$ in total length, including homology sequences of $46 \mathrm{bp}$ to $1.6 \mathrm{~kb}$ on each side of the sequence of interest $[2,6,8,10,43,67,68]$ (Table 1). As for free DNA fragments, they varied from 72 to 476 bp including homology arms, of even length or not, of 46 to 146 bp $[6,11,67,69]$. Rare are the situations (involving the same protocol, target and plant species) allowing to compare the impact of the nature and length of the homologies on knock-in efficiency. In maize, despite the fact that the targets were different, by bombarding immature embryos with a circular DNA donor template, knock-in seemed more efficient with homology sequences of $1 \mathrm{~kb}$ framing a donor cassette of $3.1 \mathrm{~kb}(2.5-4.1 \%)$, than with $0.4 \mathrm{~kb}$ homologies surrounding a $1.8 \mathrm{~kb}$ donor cassette (1\%) [2,6]. However, no absolute rules regarding the link between CRISPR- 
induced gene knock-in efficiency and the length of the homology arms can be drawn from the available data in plants. In average, a few hundred nucleotides for circular templates and a few dozens for ssDNA fragments, on each side of the cassette, are commonly used to initiate knock-in experiments in plants.

In mammalian cells, for short insertions or for gene replacement, asymmetric ssDNA donor templates with $3^{\prime}$ homology arms of $30 \mathrm{bp}$ and $5^{\prime}$ homology arms of at least $40 \mathrm{bp}$ are recommended [70]. For larger insertions, dsDNA donors with overhanging singlestranded 3' homology arms of 30 bp seemed to better support HDR than blunt ends ones [71]. Protecting the ends of these types of donor molecules with phosphorothioate modifications also improved homology-driven knock-in efficiency in mammals and allowed insertions of more than 100 bp long [71,72]. These different approaches that raised KI efficiency in animals could be interesting to inquire in plants as well, particularly the protection of the donor ends.

\subsection{Without homology to the target}

Another strategy, tested in mammals [45] and more recently in plants [3], consists in deliberately avoiding the presence of any homology arms in the donor template and counting on its integration by NHEJ-mediated repair. In various human cells targeted with the CRISPR-Cas9 system, homology-independent knock-in appeared to be more efficient than HDR-mediated gene knock-in [45]. In plants, this approach was so far only applied to rice both for the replacement of an endogenous gene and for the targeted insertion of a $1.6 \mathrm{~kb}$ dsDNA fragment. For gene replacement, two different sgRNAs were used to trigger two DSBs in the introns framing the exon to be replaced, and by using the same couple of sgRNAs to release from the donor plasmid a donor fragment bearing the modified exon (homologous to the endogenous one except for 3 nucleotides). In a few cases ( $2 \%$ of the transformed lines), the endogenous exon was deleted and then replaced by the released dsDNA fragment containing the modified exon [3]. For gene insertion, only one sgRNA was used to cleave the genomic target site and to liberate the donor fragment framed by the same target sites on the donor plasmid. End joining-mediated targeted insertion of the donor fragment was detected in $2.2 \%$ of the regenerated individuals [3], which is not much better than when using a donor template presenting homology to the target. Thus, this strategy is efficient but does not provide so far means of drastically increase CRISPR-induced gene knock-in efficiency compared to the HDR approach, as could have been expected.

\section{Optimizing cell delivery and expression of the CRISPR-Cas system}

Cell delivery is one of the key factors for efficient genome editing. Depending on the transformation protocol, the nature of the genetic elements has to be selected in order to maximize their chance of entering the cell and being correctly addressed to the nucleus and expressed simultaneously. To increase the rate of gene knock-in, minimizing the number of different molecules delivered while maximizing the number of copies of these molecules in the cell could also be determinant.

\subsection{Type of delivered molecules}

The CRISPR-Cas system can be stably or transiently transfected into the plant cells as nucleic acids (plasmids or DNA fragments) $[6,73]$ or pre-assembled ribonucleoprotein complexes (RNPs) [74-76].
Regarding the donor DNA, long donor templates (with long sequences of interest or long homology arms) can be delivered to the cells on the same or on another plasmid as the CRISPR-Cas system $[2,6,8,27,41,69]$, or as linear dsDNA fragments, provided as free molecules [67] or released in planta from a plasmid by inserting them between CRISPR target sites [3,10,67]. Shorter templates (with short homology arms or small replacement sequences) can be introduced into the cells as ssDNA oligonucleotides (sense or antisense) $[6,11,67,75]$.

The choice between these very diverse types of molecules (Fig. 1A) depends on the objectives pursued but also on the transformation protocols and the species. However, even with previous knowledge on the best transformation protocol for a given species, it is sometimes difficult to anticipate the results that will be obtained with a specific type of molecule. In rice, the introduction of a free ssDNA donor fragment (at the same time as plasmids coding for the CRISPR system) did not work by bombardment [67] but was effective by PEG fusion of protoplasts [69]. Nevertheless, if using a ssDNA donor fragment associated to two separate plasmids coding for the Cas9 protein and a sgRNA gave a good knock-in efficiency in rice (7\%) [69], it did not lead to a better efficiency $(0.3-$ $0.4 \%$ ) than when using 3 separate plasmids for the Cas9, the sgRNA and the donor template $(0.2 \%)$ in maize [6].

When using plasmids, a way to ensure the simultaneous delivery of the CRISPR-Cas system and the donor template can be to clone them on a minimum number of DNA molecules. In maize, a better gene knock-in efficiency was obtained by bombarding embryonic calli with a CRISPR-Cas9 system and a donor template cloned on the same plasmid (4.1\%) than on 3 separate plasmids (2.5\%) [6]. For multiplexing, several cloning strategies often based on the Golden Gate or Gibson assembly systems [77,78] have been developed with the corresponding backbones libraries [79-82].

\subsection{Expression and addressing}

SgRNAs are typically expressed from Pol III promoters (usually from the $U 6$ or $U 3$ genes coding for small nuclear RNAs as described previously) to prevent final polyadenylation, whereas the Cas9 protein is expressed from a Pol II promoter [83]. To synchronize the expression of these two types of elements and simplify the multiplexing of sgRNAs (that can require multiple Pol III promoters that are not always well-characterized in all species), they can be put under the control of a single Pol II promoter, which also provides greater flexibility for constitutive or inducible expression (Fig. 1B). For that matter, they can be associated to a self-cleaving ribozyme system in a single transcriptional unit (STU). The CRISPR elements are separated by ribozyme cleavage sites that serve to process them out from Pol II primary transcripts (Fig. 1B). This approach was validated in rice where it led to the same mutagenesis frequencies as the conventional twopromoters system [84].

Co-expression of sgRNAs can also be achieved by inserting their coding sequences in tandem between tRNA motifs in a single polycistronic gene under the control of a single Pol III promoter (Fig. 1B), as shown for rice [85] and wheat [86]. In this system, the transcript is cleaved using endogenous tRNA processing ribonucleases, RNases P and Z. Expression from Pol II promoters of this type of tRNA polycistronic sgRNAs has not yet been demonstrated in plants [83]. Another approach, still not tested in plants, could consist in replacing the tRNA motifs by sequences of $28 \mathrm{bp}$ recognized by Csy4, a CRISPR type III ribonuclease [87].

Very often, to increase the proportion of Cas9 protein effectively addressed to the nucleus, one or two nuclear localization signals (such as A. tumefaciens bipartite VirD2 T-DNA border endonuclease carboxyl terminal NLS, or the monopartite Simian virus 40 NLS) are 
(A)

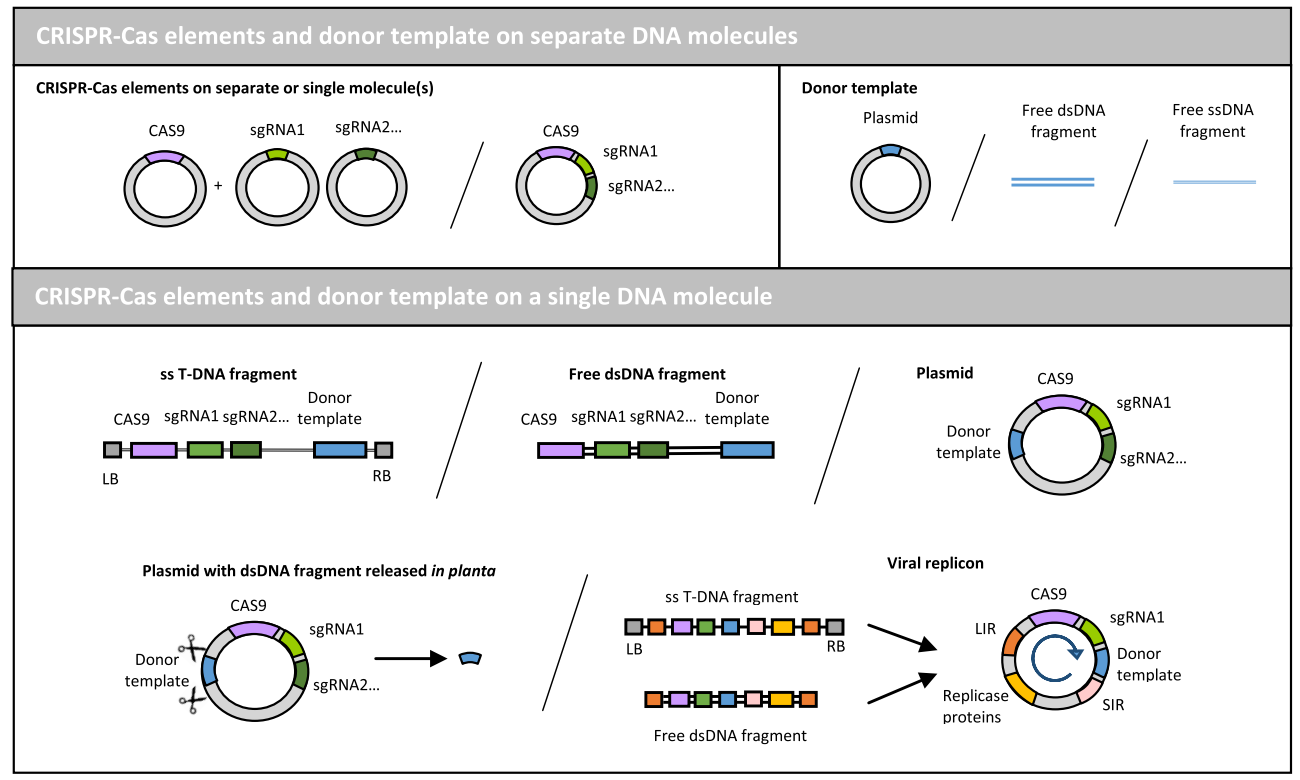

(B)

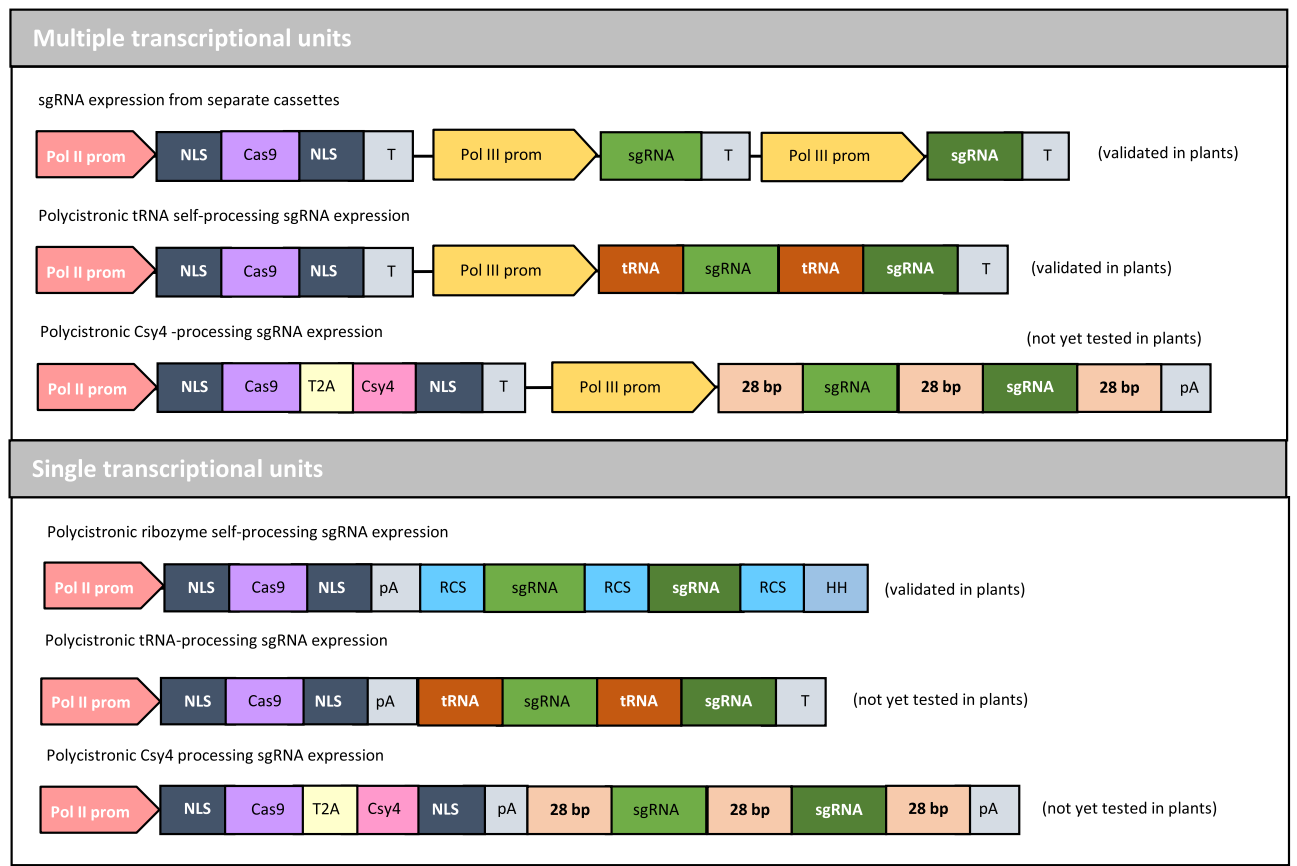

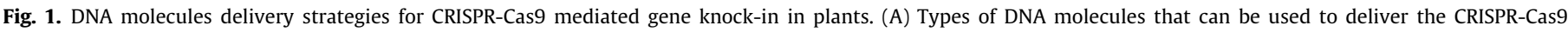

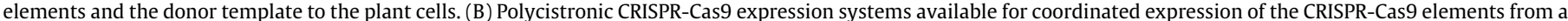

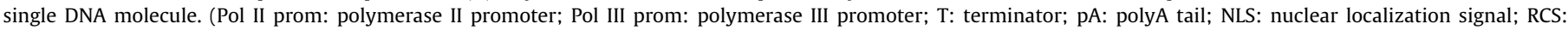
ribozyme cut site; HH: hammerhead ribozyme).

incorporated into the expression cassettes at the amino and/or carboxyl termini of the Cas9 open reading frame $[12,73,75,88]$.

Moreover, to insure a coordinated expression of the CRISPR system and delivery of the donor template, the donor cassette can be cloned between synthetic target sites for simultaneous cleavage of the genomic target and in planta release of the cassette as a dsDNA fragment (Fig. 1A) [10]. This strategy was efficient for gene knockin in rice by Agrobacterium transformation of embryonic cells whether the donor template contained homology sequences (25\% of lines regenerated on selective media) [67] or not ( $2 \%$ of lines regenerated on selective media) [3].

\subsection{Copy number}

Another key factor for CRISPR-induced gene knock-in seems to be connected to the number of copies of the delivered molecules present into the transformed plant cells, and especially those of the donor template. Indeed, biolistic co-transformation in rice with plasmids bearing a donor cassette released in planta gave higher gene knock-in efficiency with additional free dsDNA donor fragments (36\% of lines regenerated on selective media) than without (25\% of lines regenerated on selective media) [67]. 


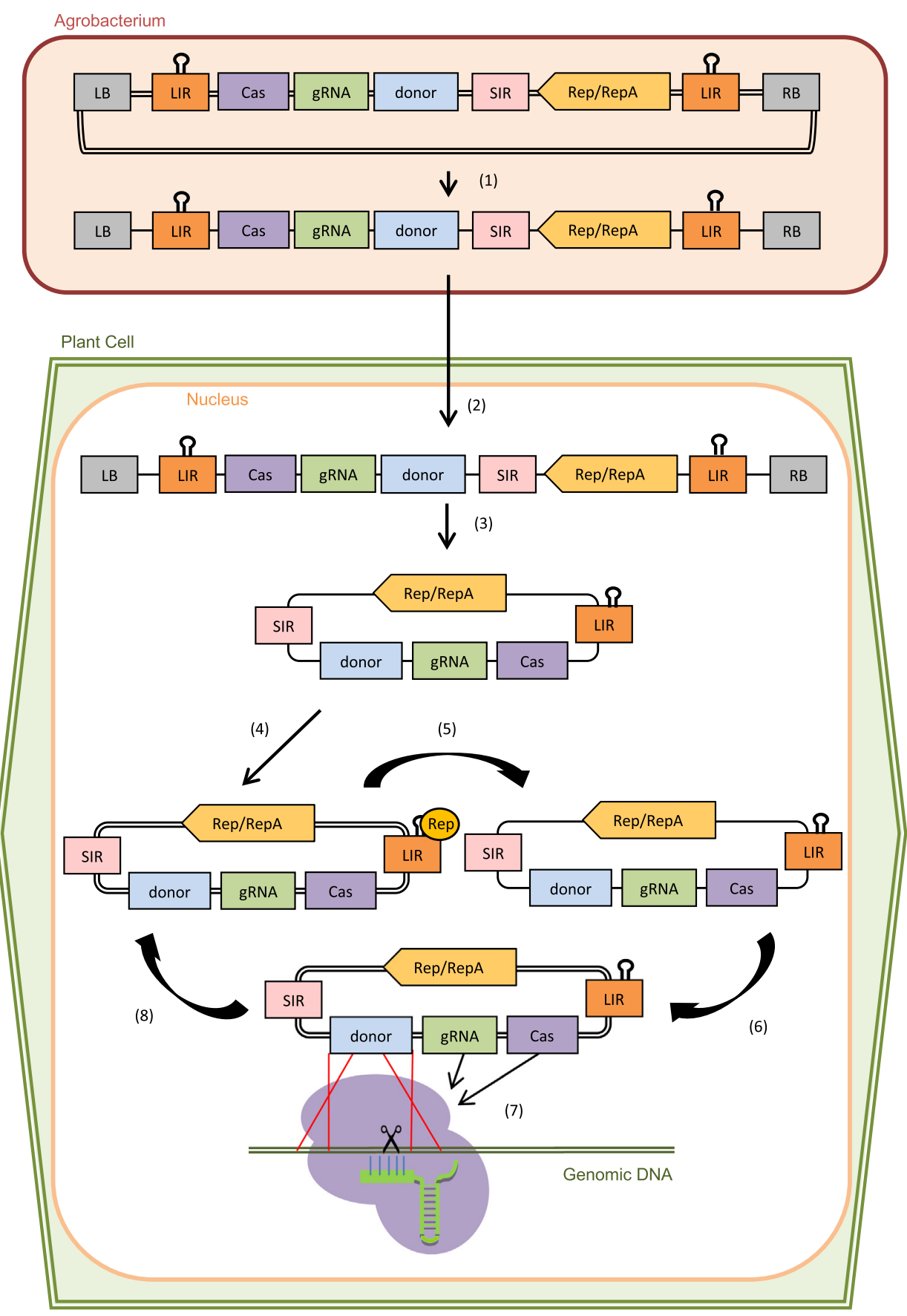

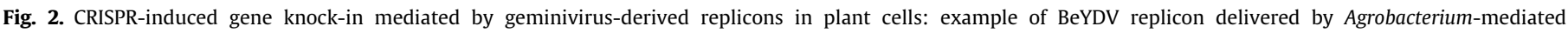

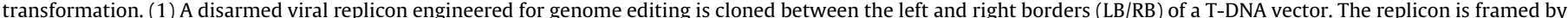

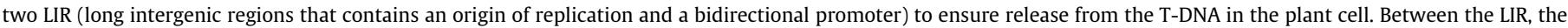

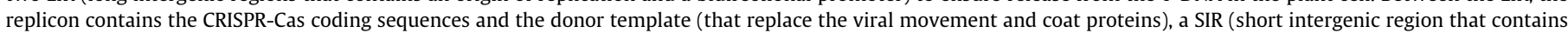

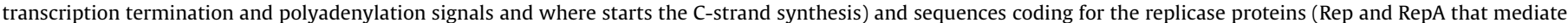

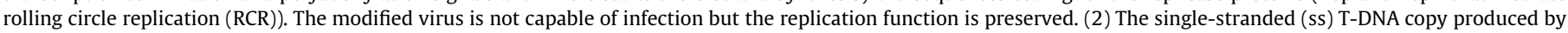

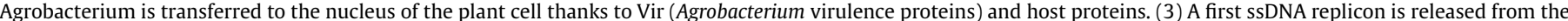

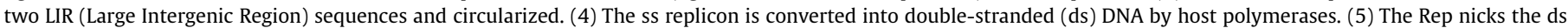

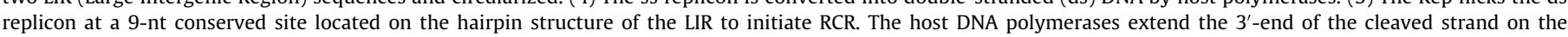

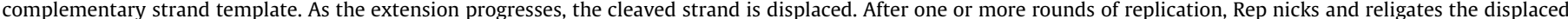

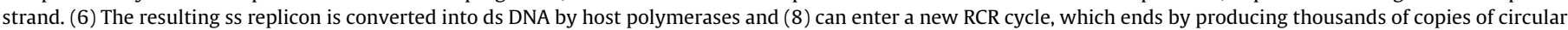

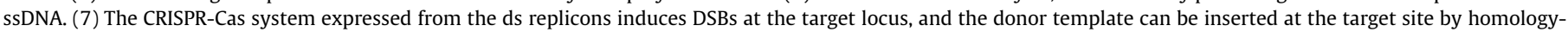
directed repair. The high copy number of nucleases and donor templates produced improves gene knock-in efficiency.

To strongly increase their copy number in the transformed cells, the sequences coding for the CRISPR-Cas9 system and the donor template can also be inserted into disarmed viral replicons of geminiviruses $[8,27,89,90]$. Other types of viral vectors, such as
Tobacco Mosaic Virus or Tobacco Rattle Virus, have been long used for transient expression of recombinant proteins in plants [91], but these viral constructs are too low cargo for the delivery of the CRISPR coding elements all together. They could be used to deliver 
split sequences of the Cas9 for the translated domains to be reassembled into a functional protein in the plant cell [92], but this option has not yet been tested in plants and viruses with higher cargo-replicons, such as geminiviruses, appeared much more adapted. Geminiviruses are single-stranded DNA viruses and replicate in the nucleus of the plant cells, which makes them very amenable to Agrobacterium transformation (transfer of the T-DNA as ssDNA) and to the production of a high number of copies of the delivered molecules in the plant cell (through the viral cycle replicating ssDNA). When the modified replicon is in the nucleus, a double-stranded intermediate is first produced by the host polymerases for expression of the viral proteins (Fig. 2). Then, the viral Rep protein creates a single-strand nick within the long intergenic region (LIR) of the (+) strand, which allows circularization and rolling-circle replication producing ssDNA molecules. The newly synthesized ssDNA can be converted into dsDNA and serve as template for the repair of the CRISPR-induced DBSs. Moreover, the viral Rep protein has a pleiotropic activity that enhances gene targeting potentially by interacting with host proteins affecting levels of HR [93]. The CRISPR elements and the donor cassette are usually integrated with the trans-acting viral polymerase Rep/RepA, the LIR and the short intergenic region (SIR) into a single plasmid to coordinate the expression of the CRISPR-Cas system and the production of a high copy number of the repair template. This approach allowed very efficient gene knock-in in tomato (3.65-11.66\% of the transfected cells, which is about 10-fold higher than with conventional Agrobacterium delivery) using the replicon backbone of BeYDV [8]. Promising results were also obtained in potato using the same strategy [27]. In theory, the BeYDV replicon could be used to mediated gene knock-in in other dicotyledonous species provided that they belong to its host range, like Arabidopsis thaliana, tobacco, Datura stramonium or French bean (Phaseolus vulgaris) (Liu et al., 1997). For monocots, other viruses from the same mastrevirus genius could be used, such as the wheat dwarf virus (WDV) or maize streak virus (MSV) [93]. Recently, a modified replicon from WDV carrying the CRISPR-Cas9 system and a repair template allowed to increase by 12 -fold the efficiency of CRISPRinduced gene knock-in (5.85\%) at an endogenous ubiquitin locus in wheat cells [94] (Table 1). This result was obtained by putting the Cas9 nuclease under the regulation of a strong promoter reinforcing the action of the replicon LIR. Simultaneous HR-mediated knock-in at two endogenous genes and in all three homeoalleles of the bread wheat genome is also reported [94].

\subsection{Transient transformation}

Stable integration into the genome of the different elements necessary to perform targeted gene knock-in can be undesirable both for plant research - to limit the potential impact of their random integration in the genome - and for plant breeding - to avoid the time-consuming rounds of backcrossing necessary to eliminate them for regulatory purposes, especially for crops with complex polyploid genomes (wheat, oat, peanut), long breeding cycles (fruit and forest trees), or that are vegetatively propagated (sugarcane, potato, cassava, banana). Transient transformation can then be performed either by direct transformation using non linearized cassettes, by Agrobacterium transformation of viral replicons that are released from the T-DNA and not integrated [94], or direct transfection of in vitro transcribed sgRNAs associated to RNA or protein versions of the Cas9 nuclease. The efficiency of the first two types of methods was demonstrated for targeted mutagenesis in different plant models and crops (as described above). Using Cas9 RNA or protein presents the advantage of not having to work on optimizing expression by defining sequences codon-optimized for the host plant and selecting appropriate promoters. Preassembled complexes of purified Cas9 protein and guide RNA (RNPs) were transfected into protoplasts of Arabidopsis thaliana, Nicotiana attenuata, Petunia $x$ hybrida, grapevine, apple, lettuce and rice $[74,76,95]$ and bombarded into immature embryos of bread and durum wheat $[73,96]$, and maize [75]. In all cases, RNPs showed good cleavage efficiency (4-46\%), with (when tested) no detectable mosaicism, suggesting a very early action of the nuclease before the first cell division [74,76]. Transient expression of the CRISPRCas9 system was also obtained by bombarding immature embryos of bread and durum wheats with in vitro transcribed sgRNAs and Cas9 RNAs. Mutagenesis frequency was lower (1.1\%) than with DNA-based transient or stable transformation performed in the same conditions (about 3\%), probably indicative of the instability of the RNAs in the plant cells [73]. Nevertheless, the rapid degradation of the RNAs is considered beneficial as it reduces the time during when the genome is exposed to nuclease activity, which limits the risk of generating off-target mutations [74]. So far, the only experiment reporting gene knock-in using a RNP complex was performed in maize by bombardment of immature embryos [75]. By using a ssDNA donor template of 127 bp bearing 7 substitutions, replacement of the target gene could be obtained with a knockin frequency of $2-2.5 \%$ [75], which is much better than the exact same experiment performed using a CRISPR-Cas9 system provided to the cell on two separate plasmids $(0.3-0.4 \%)$ [6]. This strategy could soon be applied to many other crops amenable to biolistic delivery such as wheat, barley, sorghum, rice and soybean. RNP complexes formed between Cpf1 and adapted crRNAs were also tested in soybean targeting two endogenous genes [57]. Mutagenesis frequencies ranged from 0.0 to $11.7 \%$ using LbCpf1, and from 0.0 to $1.6 \%$ using AsCpf1. So far, only SpCas9 (1368 residues) has been tested for RNP-induced knock-in in plants. It could be interesting to test some of its analogs that are smaller in size, such as SaCas9 (1053 residues), StCas9 (1121), or NmCas9 (1082) [51], or the very recently discovered CasX (980) and CasY (1200) [97], to evaluate if the delivery of the corresponding RNP complexes to the nucleus would be facilitated.

\section{Understanding and controlling the DNA repair pathways involved in CRISPR-induced KI}

Modifying the natural balance of DNA repair pathways in the cells to inhibit NHEJ or stimulate HR could be an excellent way to increase knock-in efficiency at induced DSBs. It can be achieved either by mutating or silencing the genes coding for the proteins specifically involved in these pathways or by using chemicals. For example, a significant increase in HDR was obtained by silencing individually or simultaneously proteins involved in NHEJ (ligase IV, Ku70 and Ku80) in human and mouse cells $[45,65,98,99]$. In plants, the same type of results was obtained when using ZFNs targeting the endogenous ADH1 locus in Arabidopsis thaliana. Knock-in was increased up to 16 times in the Atku70 mutant and 3 to 4 times in the Atlig4 and Atsmc6b mutants [100]. Higher rates of homology-driven knock-in were also observed in mammalian cells when using hCas9 fused to proteins involved in cell-cycle dynamics [101,102], allowing a low expression of the nuclease in G1 and a high expression during S/G2/M phases where HDR mediated repair is favored [103,104]. In mammalian cells, CRISPR-induced knock-in efficiency was improved when applying inhibitors of the NHEJ pathway, such as Scr7 (inhibiting ligaseIV) [105] or enhancers of the HDR pathway, like RS-1 [106]. A method for high-throughput identification of small chemical compounds capable of enhancing CRISPR-mediated HDR efficiency by 3-fold for large insertions and 9-fold for gene replacement was developed in mammalian cells [107]. These different approaches could be worth exploring to better control CRISPR- 
assisted genome editing in plants and to progress in the understanding of the cellular mechanisms involved.

Even if CRISPR-induced DSBs can significantly increase the very low basal level of GT in plants (varying from 0.01 to $0.1 \%$ ) [64,108], studying gene knock-in in these species still remains uneasy. However, there is one exception in the plant kingdom, the moss Physcomitrella patens, that exhibits rates of GT comparable to S. cerevisiae and has permitted important advances in the comprehension of HR-mediated DNA repair and transgene integration via GT in plants [109]. Its ability to naturally perform GT at a high level combined to easy in vitro protocols and a fully sequenced genome make this bryophyte an excellent model for the deciphering of the different DNA repair pathways involved in CRISPR-assisted knock-in in plants.

The CRISPR-Cas9 system was successfully applied to $P$. patens for targeted mutagenesis using up to 5 sgRNAs simultaneously $[41,110]$. The mutations observed included a diversity of deletions, insertions and/or substitutions mainly resulting from NHEJ, but also deletions resulting from microhomology-mediated end joining (MMEJ) when micro-homologies were located on both sides of the cleavage sites [41].

CRISPR-induced knock-in was studied by using one sgRNA targeting an endogenous reporter gene coding for the adenine phosphoribosyl transferase (PPAPT) whose loss of function confers resistance to the toxic compound 2-fluoroadenine (2-FA) [111]. Three separate plasmids carrying the Cas9, the sgRNA and a donor template bearing an antibiotic resistance gene framed by homologies to the reporter gene PpAPT were co-transformed by PEG fusion of protoplasts [41]. As previously described in P. patens [111-114] and as frequently observed in other plants [115], the donor DNA template can be inserted in two different ways: either by homologous recombination on both sides leading to targeted gene replacement (TGR) or by HDR on one side and NHEJ on the other upstream or downstream of the targeted locus, leading to targeted gene insertions (TGI). For both these types of events, the insertions frequently contain multiple copies of the donor template $[116,117]$. When Cas9 cleaves the target site, it can be repaired either by insertion of the donor template (TGR or TGI events) or by NHEJ potentially inducing mutations which leads in both cases to the disruption of the target gene. To discriminate between these events and evaluate knock-in frequency, regeneration was performed on selective media containing either 2-FA or the antibiotic, and the target site of the resistant clones was genotyped with appropriate primers. Knock-in frequency was expressed as the number of clones having integrated the donor cassette at the target site divided by the number of clones having integrated this cassette anywhere in the genome. With the CRISPR-Cas9 system, knock-in efficiency was significantly increased reaching almost $100 \%$ of the transformed plants (compared to $54 \%$ in the classical approach). Thus, when using CRISPR, if the donor template is integrated in the genome of $P$. patens, it appears to be always at the target site. Nevertheless, $40 \%$ of the Cas9-induced DSBs are not repaired by HDR, but by mutagenic illegitimate recombination (IR, NHEJ or MMEJ), meaning that in $P$. patens both HDR and IR are equally proficient to repair Cas9-induced genomic DSBs. The ratio between TGR and TGI events was identical, but the proportion of plants with a single copy replacement was significantly higher with CRISPR (40.5\%) than without (15\%). Classical GT in P. patens was recently described as dependent on the classical RAD51mediated HR repair pathway $[112,113,118]$. Interestingly, with CRISPR, HDR-mediated knock-in was reduced but not abolished (as it is without CRISPRs) in the Pprad51-1-2 double mutant, reaching about $30 \%$ of the wild type level. This proves that other types of DNA repair pathways are involved in the integration of the donor template when a DSB is induced at the chromosomal target gene [41].
To confirm the results obtained on the impact of the CRISPRCas9 system on the nature and the frequency of knock-in events in $P$. patens, another experiment in similar conditions was performed by targeting a non-selectable endogenous gene (PpPIF1.2, a DNA helicase) with 2 sgRNAs and using a circular donor template containing an antibiotic resistance cassette surrounded by two homology arms of about 600 bp (Fig. 3A). SgRNAs were designed to induce cleavage in the vicinity of the start and stop codons of the target gene, potentially resulting in the deletion of the coding sequence and its replacement by the donor template. The transformed individuals were regenerated on the antibiotic and genotyped using the primers described (Fig. 3B). As shown in Table 2, knock-in efficiency was again of $100 \%$ (no random insertion by IR) and the proportion of single copy replacement was significantly higher $(64 \%(53 / 82))$ than without CRISPR (5\% (1/20)). Moreover, the ratio between TGR and TGI was also higher with CRISPRs (89\% (73/82)) than without $(60 \%(3 / 5))$, showing that for gene replacement, just like for gene insertion induced by a single DSB, inducing two simultaneous DSBs on each side of the target is also a way to facilitate TGR and limit the production of unwanted TGI events. No insertion of the donor cassette was observed at only one of the DSBs, as it was for example reported for $0.2 \%$ of the transformed plants when inducing two targeted DSBs for the replacement of an exon of the EPSPS endogenous locus in rice [3].

In conclusion, by inducing one or two concurrent DSBs at the target site, the CRISPR-Cas9 system significantly improves knockin efficiency and precision in $P$. patens. These results reveal novel features of CRISPR-induced HDR-mediated knock-in that could lead to improve the efficiency of gene knock-in in plants. Further work in different mutant backgrounds should allow to progress in the elucidation of the respective contributions of the different DNA repair pathways involved.

\section{Conclusion and future challenges}

Mastering gene knock-in is a prerequisite to the full exploitation of the CRISPR-Cas system potentialities in plant research and plant breeding. Many different aspects, including regeneration protocols, design and delivery of genetic elements, orientation of DNA repair pathways, can be investigated to reach this objective. Improving CRISPR-mediated knock-in efficiency will result from the optimization of all these parameters combined together. However, some key features seem to arise from the already available data. Among them, one of the most important seems to be the delivery of the CRISPR-Cas elements and the donor templates, and more specifically the possibility to synchronize their expression and increase their copy numbers, especially those of the donor templates. Indeed, the best efficiencies so far were obtained when using viral replicons allowing rolling circle amplification of the delivered molecules inside the plant cells, or when providing supplementary ssDNA donor fragments in addition to donor templates released from plasmids in planta. Protecting the ends of free donor DNA fragments by chemical modifications could also contribute to a better KI efficiency as demonstrated in mammals. Another very promising area of investigation is the alteration of DNA repair pathways to favor gene insertion. This could be done by bringing proteins involved in DSB processing or HR, for example fused to the nuclease, or by orienting the cellular context towards HDR by applying drugs to the regenerating material or by silencing or activating specific DNA repair proteins, for instance by using transiently expressed or inducible dCas9 fused to transcription factors (transitory activation of these proteins being important to avoid genetic instability).

The necessity to avoid the stable integration of undesired transgenes for scientific or regulatory purposes will favor the 
(A)

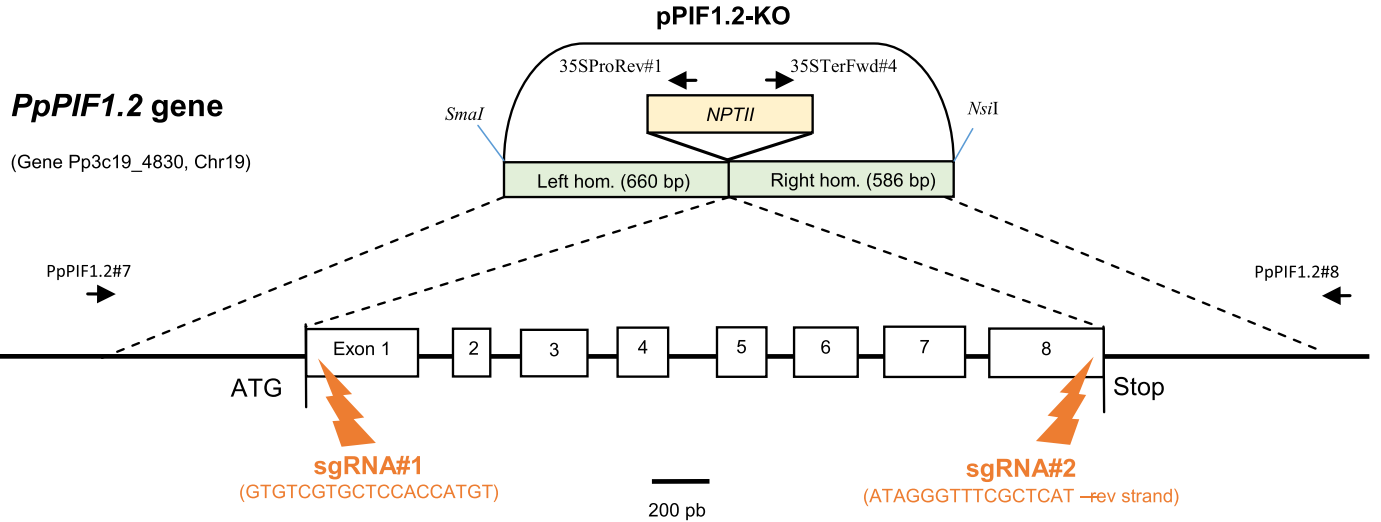

(B)

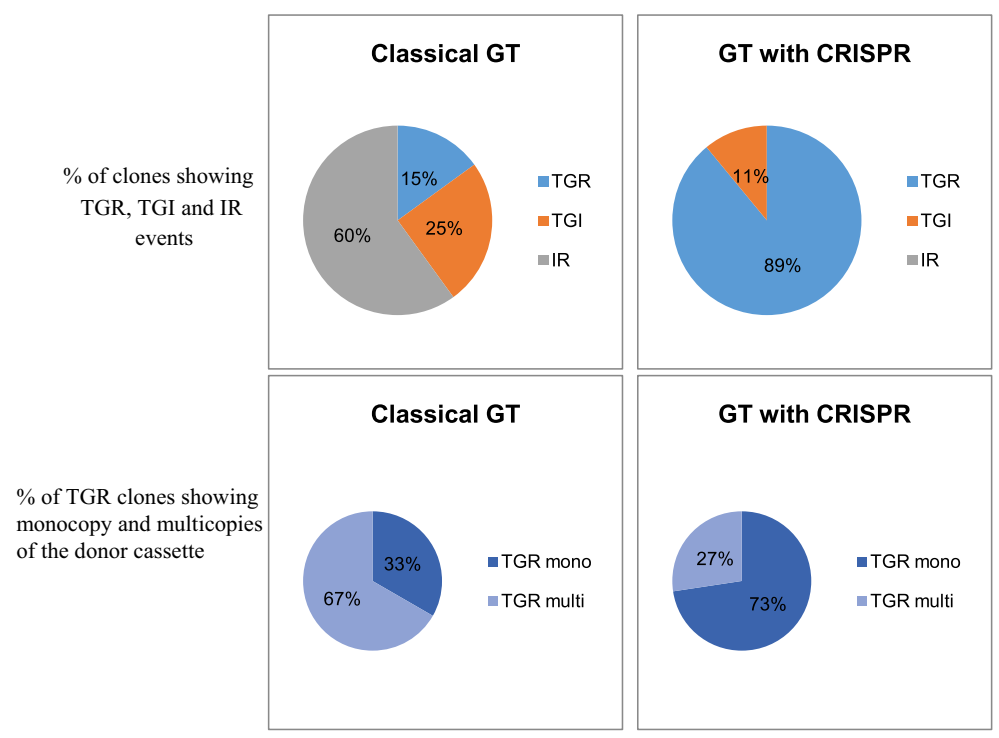

Fig. 3. Comparison of PPPIF1.2 gene targeting efficiency using the "CRISPR-Cas9" versus "classical" mediated transformations. (A) Description of PpPIF1.2 gene with the target sites and of the donor cassette (PIF1.2-KO) used for gene targeting experiments (white rectangles represent exons). For "CRISPR-Cas9" mediated transformation, protoplasts were co-transformed with pAct-Cas9 [41], psgRNA\#1 and psgRNA\#2, and the circular pPIF1.2-KO bearing the donor DNA cassette. The sgRNAs under the control of the PpU6 promoter were synthesized as gBlocks ${ }^{\circledast}$ by IDT (www.idtdna.com) using the tracRNA backbone from Mali et al., 2013 [120] and cloned into pDONR207 by Gateway ${ }^{\circledast}$. The donor cassette PIF1.2-KO contains PCR-amplified homology arms of 660 bp [coordinate 2752743 on Pp3c19_483 in Phytozome] and 586 bp [coordinate 2755103 on Pp3c19_483 in Phytozome] cloned on each side of the $35 \mathrm{~S}:$ :neoR cassette from pBNRf for resistance to G418 [113]. For "classical" transformation, protoplasts were transformed with linearized PIF1.2-KO donor DNA cassette. (B) Summary of genotyping results, sequences of the primers used with an example of the gel patterns obtained. Protoplasts from the Gransden wild type strain of P. patens [121] were transformed by PEG fusion [117]. Whole plants were regenerated on medium containing G418 and the resistant individuals were genotyped by PCR. $(\mathrm{GT}=$ Gene targeting; TGR = Targeted gene replacement events $(\mathrm{TGR}$ mono = with monocopy insertions; TGR multi = with multicopies insertions); TGI = Targeted gene insertion events; $I R=$ Resistant clones showing a WT pattern at the target site, corresponding to random insertion events produced by illegitimate repair, meaning by NHEJ or MMEJ).

Table 2

Comparison of knock-in efficiency using the "CRISPR-Cas9 system with 2 sgRNAs" vs. "classical" mediated transformations to target the non-selectable endogenous gene PpPIF1.2.

\begin{tabular}{|c|c|c|c|c|c|c|}
\hline \multirow[t]{2}{*}{ Type of transformation } & \multirow[t]{2}{*}{$\operatorname{RTF}^{\mathrm{a}} \%$} & \multirow[t]{2}{*}{$\mathrm{AB}^{\mathrm{R}}$ clones } & \multirow[t]{2}{*}{ Integration due to $\mathrm{IR}^{\mathrm{b}}$} & \multicolumn{2}{|c|}{ Integration due to $\mathrm{HDR}^{\mathrm{c}}$} & \multirow[t]{2}{*}{$\mathrm{GT}^{\mathrm{d}} \%$} \\
\hline & & & & TGR & TGI (5'TGI + 3'TGI) & \\
\hline “CRISPR-Cas9” & 0.9 & 82 & 0 & 73 (53 mono) & $9(8+1)$ & 100 \\
\hline “classical” & 0.04 & 20 & 12 & 3 (1 mono) & $5(0+5)$ & 40 \\
\hline
\end{tabular}

${ }^{a}$ Relative Transformation Frequencies (RTF) express the frequency of stable $A B^{R}$ clones in the population of regenerated clones. A total of 400 and $46 A B^{R}$ clones were obtained for the "CRISPR-Cas9" and "classical" methods of transformation respectively.

${ }^{b}$ Number of $A B^{R}$ clones where the donor DNA template has been randomly inserted by illegitimate recombination (IR, meaning NHEJ or MMEJ) and not via HDR.

${ }^{c}$ Number of $A B^{R}$ clones resulting from HDR (TGR or TGI) mediated insertion of the donor DNA template at the PpPIF1 locus was determined by PCR analysis (using the primers described in (A) and below). Clones resulting from $5^{\prime}$ TGI show only a $5^{\prime}$ junction (primers PpPIF1.2\#7 + 35SProRev\#1); clones resulting from $3^{\prime}$ TGI show only a $3^{\prime}$ junction (primers PpPIF1.2\#8 + 35TerFwd\#4); clones resulting from TGR show $5^{\prime}$ and $3^{\prime}$ junctions. In brackets, are indicated the number of TGR clones showing monocopy insertion of the donor cassette detected by using PpPIF1.2\#7 + \#8.

${ }^{\mathrm{d}}$ GT efficiencies (\%) express the frequency of clones presenting HDR insertions among the population of antibiotic resistant transgenic clones. 
development of vector-free delivery methods such as the RNP strategy. The recently demonstrated possibility of introducing the complexes via biolistic opens the way for genome editing in many species for which the regeneration of fertile plants from protoplasts is inefficient or limited to certain genotypes.

For a few major crops, the integration of the CRISPR-Cas9 tool into selection schemes is on its way, and the first CRISPR varieties should be released on the market in a few years. The first edited traits of interest will probably be well characterized agronomic attributes (such as waxy starch) inserted in performant backgrounds [119] but, in the long term, new characteristics could be developed regarding biotic and abiotic stresses, yield, plant physiology (biomass, life cycle), nutritional and industrial qualities, and the production of therapeutic molecules. Moreover, efficient CRISPR-induced gene knock-in protocols should enhance the exploration of genetic resources and contribute to the creation of a new genetic diversity essential for the development of varieties adapted to the next agricultural challenges (productivity with limited inputs, durable management of biological resources, integrated pest management, adaptation to climate changes, ...). Much work needs to be done to be able to perform CRISPRinduced gene knock-in with high efficiency in all plant species of interest, but if the socio-economic and regulatory context allows for the necessary investments, many promising avenues are available for advances.

\section{Acknowledgements}

This work was supported by the French government through the programme "Investissements d'Avenir" and by the French National Research Agency, in the frame of the research project called "GENIUS" (Genome ENgineering Improvement for Useful plants of a Sustainable agriculture), ref \# ANR11-BTBR-0001GENIUS.

\section{References}

[1] L. Bortesi, R. Fischer, The CRISPR/Cas9 system for plant genome editing and beyond, Biotechnol. Adv. 33 (2015) 41-52, http://dx.doi.org/10.1016/j. biotechadv.2014.12.006.

[2] J. Shi, H. Gao, H. Wang, H.R. Lafitte, R.L. Archibald, M. Yang, S.M. Hakimi, H. Mo, J.E. Habben, ARGOS8 variants generated by CRISPR-Cas9 improve maize grain yield under field drought stress conditions, Plant Biotechnol. J. (2016) http://dx.doi.org/10.1111/pbi.12603.

[3] J. Li, X. Meng, Y. Zong, K. Chen, H. Zhang, J. Liu, J. Li, C. Gao, Gene replacements and insertions in rice by intron targeting using CRISPR-Cas9, Nat. Plants 2 (2016) 16139, http://dx.doi.org/10.1038/nplants.2016.139.

[4] M.J. Sadhu, J.S. Bloom, L. Day, L. Kruglyak, CRISPR-directed mitotic recombination enables genetic mapping without crosses, Science 352 (2016) 1113-1116, http://dx.doi.org/10.1126/science.aaf5124

[5] A. Piatek, Z. Ali, H. Baazim, L. Li, A. Abulfaraj, S. Al-Shareef, M. Aouida, M.M. Mahfouz, RNA-guided transcriptional regulation in planta via synthetic dCas9-based transcription factors, Plant Biotechnol. J. 13 (2015) 578-589, http://dx.doi.org/10.1111/pbi.12284.

[6] S. Svitashev, J.K. Young C. Schwartz, H. Gao, S.C. Falco, A.M. Cigan, Targeted Mutagenesis, Precise Gene Editing, and Site-Specific Gene Insertion in Maize Using Cas9 and Guide RNA, Plant Physiol. 169 (2015) 931-945, http://dx.doi org/10.1104/pp.15.00793.

[7] C. Ren, X. Liu, Z. Zhang, Y. Wang, W. Duan, S. Li, Z. Liang, CRISPR/Cas9 mediated efficient targeted mutagenesis in Chardonnay (Vitis vinifera L.), Sci. Rep. 6 (2016) 1-9, http://dx.doi.org/10.1038/srep32289.

[8] T. Cermák, N.J. Baltes, R. Cegan, Y. Zhang, D.F. Voytas, High-frequency, precise modification of the tomato genome, Genome Biol. 16 (2015) 232, http://dx. doi.org/10.1186/s13059-015-0796-9.

[9] Q. Li, D. Zhang, M. Chen, W. Liang, J. Wei, Y. Qi, Z. Yuan, Development of japonica Photo-Sensitive Genic Male Sterile Rice Lines by Editing Carbon Starved Anther Using CRISPR/Cas9, J. Genet. Genomics 43 (2016) 415-419 http://dx.doi.org/10.1016/j.jgg.2016.04.011.

[10] S. Schiml, F. Fauser, H. Puchta, The CRISPR/Cas system can be used as nuclease for in planta gene targeting and as paired nickases for directed mutagenesis in Arabidopsis resulting in heritable progeny, Plant J. 80 (2014) 1139-1150, http://dx.doi.org/10.1111/tpj.12704.

[11] Q. Shan, Y. Wang, J. Li, C. Gao, Genome editing in rice and wheat using the CRISPR/Cas system, Nat. Protoc. 9 (2014) 2395-2410, http://dx.doi.org/ 10.1038/nprot.2014.157.
[12] W. Jiang, H. Zhou, H. Bi, M. Fromm, B. Yang, D.P. Weeks, Demonstration of CRISPR/Cas9/sgRNA-mediated targeted gene modification in Arabidopsis, tobacco, sorghum and rice, Nucleic Acids Res. 41 (2013), http://dx.doi.org/ 10.1093/nar/gkt780. e188-e188.

[13] Y. Wang, X. Cheng, Q. Shan, Y. Zhang, J. Liu, C. Gao, J. Qiu, Simultaneous editing of three homoeoalleles in hexaploid bread wheat confers heritable resistance to powdery mildew, Nat. Biotechnol. 32 (2014) 947-951, http://dx. doi.org/10.1038/nbt.2969.

[14] J. Chandrasekaran, M. Brumin, D. Wolf, D. Leibman, C. Klap, M. Pearlsman, A Sherman, T. Arazi, A. Gal-On, Development of broad virus resistance in nontransgenic cucumber using CRISPR/Cas9 technology, Mol. Plant Pathol. 17 (2016) 1140-1153, http://dx.doi.org/10.1111/mpp.12375.

[15] Y. Ito, A. Nishizawa-Yokoi, M. Endo, M. Mikami, S. Toki, CRISPR/Cas9mediated mutagenesis of the RIN locus that regulates tomato fruit ripening, Biochem. Biophys. Res. Commun. 467 (2015) 76-82, http://dx.doi.org/ 10.1016/j.bbrc.2015.09.117.

[16] M. Li, X. Li, Z. Zhou, P. Wu, M. Fang, X. Pan, Q. Lin, W. Luo, G. Wu, H. Li, Reassessment of the Four Yield-related Genes Gn1a, DEP1, GS3, and IPA1 in Rice Using a CRISPR/Cas9 System., Front, Plant Sci. 7 (2016) 377, http://dx.doi. org/10.3389/fpls.2016.00377.

[17] R. Xu, Y. Yang, R. Qin, H. Li, C. Qiu, L. Li, P. Wei, J. Yang, Rapid improvement of grain weight via highly efficient CRISPR/Cas9-mediated multiplex genome editing in rice, J. Genet. Genomics 43 (2016) 529-532, http://dx.doi.org/ 10.1016/j.jgg.2016.07.003.

[18] T. Sovová, G. Kerins, K. Demnerová, J. Ovesná, Genome editing with engineered nucleases in economically important animals and plants: state of the art in the research pipeline, Curr. Issues Mol. Biol. 21 (2016) 41-62. http://www.ncbi.nlm.nih.gov/pubmed/27253613.

[19] T. Lawrenson, O. Shorinola, N. Stacey, C. Li, L. Østergaard, N. Patron, C. Uauy, W. Harwood, Induction of targeted, heritable mutations in barley and Brassica oleracea using RNA-guided Cas9 nuclease, Genome Biol. (2015) 113, http://dx.doi.org/10.1186/s13059-015-0826-7.

[20] H. Li, M. Soriano, J. Cordewener, J.M. Muiño, T. Riksen, H. Fukuoka, G.C Angenent, K. Boutilier, The histone deacetylase inhibitor trichostatin a promotes totipotency in the male gametophyte, Plant Cell 26 (2014) 195209, http://dx.doi.org/10.1105/tpc.113.116491.

[21] K. Lowe, E. Wu, N. Wang, G. Hoerster, C. Hastings, M. Cho, C. Scelonge, B. Lenderts, M. Chamberlin, J. Cushatt, L. Wang, L. Ryan, T. Khan, J. Chow-Yiu, W. Hua, M. Yu, J. Banh, Z. Bao, K. Brink, E. Igo, B. Rudrappa, P. Shamseer, W. Bruce, L. Newman, B. Shen, P. Zheng, D. Bidney, C. Falco, J. Register, Z.-Y. Zhao, D. Xu, T. Jones, W. Gordon-Kamm, Morphogenic Regulators Baby boom and Wuschel Improve Monocot Transformation, Plant Cell 28 (2016) 19982015, http://dx.doi.org/10.1105/tpc.16.00124.

[22] A. Iwase, K. Mita, S. Nonaka, M. Ikeuchi, C. Koizuka, M. Ohnuma, H. Ezura, J Imamura, K. Sugimoto, WIND1-based acquisition of regeneration competency in Arabidopsis and rapeseed, J. Plant. Res. 128 (2015) 389-397, http://dx.doi.org/10.1007/s10265-015-0714-y.

[23] S. Mayavan, K. Subramanyam, B. Jaganath, D. Sathish, M. Manickavasagam, A. Ganapathi, Agrobacterium-mediated in planta genetic transformation of sugarcane setts, Plant Cell Rep. 34 (2015) 1835-1848, http://dx.doi.org/ 10.1007/s00299-015-1831-8.

[24] S. Subramanyam, W.T. Jones, M. Spies, M.A. Spies, Contributions of the RAD51 $\mathrm{N}$-terminal domain to BRCA2-RAD51 interaction, Nucleic Acids Res. 41 (2013) 9020-9032, http://dx.doi.org/10.1093/nar/gkt691.

[25] C. Morineau, Y. Bellec, F. Tellier, L. Gissot, Z. Kelemen, F. Nogué, J.-D. Faure, Selective gene dosage by CRISPR-Cas9 genome editing in hexaploid Camelina sativa, Plant Biotechnol. J. (2016), http://dx.doi.org/10.1111/ pbi.12671.

[26] Z. Feng, Y. Mao, N. Xu, B. Zhang, P. Wei, D.-L. Yang, Z. Wang, Z. Zhang, R. Zheng, L. Yang, L. Zeng, X. Liu, J.-K. Zhu, Multigeneration analysis reveals the inheritance, specificity, and patterns of CRISPR/Cas-induced gene modifications in Arabidopsis, Proc. Natl. Acad. Sci. 111 (2014) 4632-4637, http://dx.doi.org/10.1073/pnas.1400822111.

[27] N.M. Butler, N.J. Baltes, D.F. Voytas, D.S. Douches, Geminivirus-mediated genome editing in potato (Solanum tuberosum L.) using sequence-specific nucleases, Front. Plant Sci. 7 (2016) 1-13, http://dx.doi.org/10.3389/ fpls.2016.01045.

[28] R. Terada, H. Urawa, Y. Inagaki, K. Tsugane, S. Iida, Efficient gene targeting by homologous recombination in rice, Nat. Biotechnol. 20 (2002) 1030-1034, http://dx.doi.org/10.1038/nbt737.

[29] Z. Shimatani, A. Nishizawa-Yokoi, M. Endo, S. Toki, R. Terada, Positivenegative-selection-mediated gene targeting in rice, Front. Plant Sci. 5 (2015) 1-7, http://dx.doi.org/10.3389/fpls.2014.00748

[30] F. Hahn, O. Mantegazza, A. Greiner, P. Hegemann, M. Eisenhut, A.P.M. Weber, An efficient visual screen for CRISPR/Cas9 activity in Arabidopsis thaliana, Front. Plant Sci. 8 (2017) 39, http://dx.doi.org/10.3389/fpls.2017.00039.

[31] M. Jinek, K. Chylinski, I. Fonfara, M. Hauer, J.A. Doudna, E. Charpentier, A programmable dual-RNA-guided DNA endonuclease in adaptive bacterial immunity, Science 337 (2012) 816-821, http://dx.doi.org/ 10.1126/science.1225829.

[32] M. Haeussler, J.-P. Concordet, Genome Editing with CRISPR-Cas9: Can It Get Any Better?, J Genet. Genomics 43 (2016) 239-250, http://dx.doi.org/ 10.1016/j.jgg.2016.04.008.

[33] Y. Dang, G. Jia, J. Choi, H. Ma, E. Anaya, C. Ye, P. Shankar, H. Wu, Optimizing sgRNA structure to improve CRISPR-Cas9 knockout efficiency, Genome Biol. 16 (2015) 280, http://dx.doi.org/10.1186/s13059-015-0846-3. 
[34] R. Xu, R. Qin, H. Li, D. Li, L. Li, P. Wei, J. Yang, Generation of targeted mutant rice using a CRISPR-Cpf1 system., Plant Biotechnol. J. (2016) in press, DOI: 10.1111/pbi.12669. doi:10.1111/pbi.12669.

[35] S.H. Sternberg, B. LaFrance, M. Kaplan, J.A. Doudna, Conformational control of DNA target cleavage by CRISPR-Cas9, Nature 527 (2015) 1-14, http://dx.doi. org/10.1038/nature 15544

[36] H. Xu, T. Xiao, C.-H. Chen, W. Li, C.A. Meyer, Q. Wu, D. Wu, L. Cong, F. Zhang, J. S. Liu, M. Brown, X.S. Liu, Sequence determinants of improved CRISPR sgRNA design, Genome Res. 25 (2015) 1147-1157, http://dx.doi.org/10.1101/ gr.191452.115.

[37] N. Wong, W. Liu, X. Wang, WU-CRISPR: characteristics of functional guide RNAs for the CRISPR/Cas9 system, Genome Biol. 16 (2015) 218, http://dx.doi. org/10.1186/s13059-015-0784-0.

[38] Y. Ding, H. Li, L.-L. Chen, K. Xie, Recent advances in genome editing using CRISPR/Cas9, Front. Plant Sci. 7 (2016) 703, http://dx.doi.org/10.3389/ fpls.2016.00703.

[39] X. Ren, Z. Yang, J. Xu, J. Sun, D. Mao, Y. Hu, S.-J. Yang, H.-H. Qiao, X. Wang, Q. Hu, P. Deng, L.-P. Liu, J.-Y. Ji, J.B. Li, J.-Q. Ni, Enhanced specificity and efficiency of the CRISPR/Cas9 system with optimized sgRNA parameters in Drosophila, Cell Rep. 9 (2014) 1151-1162, http://dx.doi.org/10.1016/j.celrep. 2014.09.044.

[40] B. Farboud, B.J. Meyer, Dramatic enhancement of genome editing by CRISPR/ Cas9 through improved guide RNA design, Genetics 199 (2015) 959-971, http://dx.doi.org/10.1534/genetics.115.175166.

[41] C. Collonnier, A. Epert, K. Mara, F. Maclot, A. Guyon-Debast, F. Charlot, C. White, D.G. Schaefer, F. Nogué, CRISPR-Cas9-mediated efficient directed mutagenesis and RAD51-dependent and RAD51-independent gene targeting in the moss Physcomitrella patens, Plant Biotechnol. J. (2016) 1-10, http://dx. doi.org/10.1111/pbi.12596.

[42] J. Miao, D. Guo, J. Zhang, Q. Huang, G. Qin, X. Zhang, J. Wan, H. Gu, L.-J. Qu, Targeted mutagenesis in rice using CRISPR-Cas system, Cell Res. 23 (2013) 1233-1236, http://dx.doi.org/10.1038/cr.2013.123.

[43] O. Shan, Y. Wang, J. Li, Y. Zhang, K. Chen, Z. Liang, K. Zhang, J. Liu, J.J. Xi, J.-L. Qiu, C. Gao, Targeted genome modification of crop plants using a CRISPR-Cas system, Nat. Biotechnol. 31 (2013) 686-688, http://dx.doi.org/10.1038/ nbt.2650.

[44] F. Fauser, S. Schiml, H. Puchta, Both CRISPR/Cas-based nucleases and nickases can be used efficiently for genome engineering in Arabidopsis thaliana, Plant J. 79 (2014) 348-359, http://dx.doi.org/10.1111/tpj.12554.

[45] X. He, C. Tan, F. Wang, Y. Wang, R. Zhou, D. Cui, W. You, H. Zhao, J. Ren, B. Feng, Knock-in of large reporter genes in human cells via CRISPR/Cas9induced homology-dependent and independent DNA repair, Nucleic Acids Res. 44 (2016), http://dx.doi.org/10.1093/nar/gkw064. e85-e85.

[46] A.C. Komor, Y.B. Kim, M.S. Packer, J.A. Zuris, D.R. Liu, Programmable editing of a target base in genomic DNA without double-stranded DNA cleavage, Nature 61 (2016) 5985-5991, http://dx.doi.org/10.1038/nature17946.

[47] Y. Zong, Y. Wang, C. Li, R. Zhang, K. Chen, Y. Ran, J. Qiu, D. Wang, C. Gao Precise base editing in rice, wheat and maize with a Cas9- cytidine deaminase fusion, (2017) 4-7. doi:10.1038/nbt.3811.

[48] J. Li, Y. Sun, J. Du, Y. Zhao, L. Xia, Generation of targeted point mutations in rice by a modified CRISPR/Cas9 system, Mol. Plant. (2016) 526-529, http://dx. doi.org/10.1016/j.molp.2016.12.001.

[49] Y. Lu, J. Zhu, Precise editing of a target base in the rice genome using a modified CRISPR/Cas9 system, Mol. Plant. (2016) 523-525, http://dx.doi.org/ 10.1016/j.molp.2016.11.013

[50] Z. Shimatani, S. Kashojiya, M. Takayama, R. Terada, T. Arazoe, H. Ishii, H. Teramura, T. Yamamoto, H. Komatsu, K. Miura, H. Ezura, K. Nishida, T. Ariizumi, A. Kondo, Targeted base editing in rice and tomato using a CRISPRCas9 cytidine deaminase fusion, Nat. Biotechnol. (2017) 3-8, http://dx.doi. org/10.1038/nbt.3833.

[51] A.C. Komor, A.H. Badran, D.R. Liu, CRISPR-based technologies for the manipulation of eukaryotic genomes, Cell 168 (2016) 1-17, http://dx.doi. org/10.1016/j.cell.2016.10.044.

[52] J. Steinert, S. Schiml, F. Fauser, H. Puchta, Highly efficient heritable plant genome engineering using Cas9 orthologues from Streptococcus thermophilus and Staphylococcus aureus, Plant J. 84 (2015) 1295-1305, http://dx.doi.org/ $10.1111 /$ tpj.13078.

53] A.V. Wright, J.K. Nuñez, J.A. Doudna, Biology and applications of CRISPR systems: harnessing nature's toolbox for genome engineering, Cell 164 (2016) 29-44, http://dx.doi.org/10.1016/j.cell.2015.12.035.

[54] S. Shmakov, O.O. Abudayyeh, K.S. Makarova, Y.I. Wolf, J.S. Gootenberg, E Semenova, L. Minakhin, J. Joung, S. Konermann, K. Severinov, F. Zhang, E.V. Koonin, Discovery and functional characterization of diverse class 2 CRISPRCas systems, Mol. Cell 60 (2015) 385-397, http://dx.doi.org/10.1016/ j.molcel.2015.10.008.

[55] I. Fonfara, H. Richter, M. Bratovič, A. Le Rhun, E. Charpentier, The CRISPRassociated DNA-cleaving enzyme Cpf1 also processes precursor CRISPR RNA, Nature 532 (2016) 517-521, http://dx.doi.org/10.1038/nature17945.

[56] X. Hu, C. Wang, Q. Liu, Y. Fu, K. Wang, Targeted mutagenesis in rice using CRISPR-Cpf1 system, J. Genet. Genomics 44 (2016) 2016-2018, http://dx.doi. org/10.1016/j.jgg.2016.12.001.

[57] H. Kim, S.-T. Kim, J. Ryu, B.-C. Kang, J.-S. Kim, S.-G. Kim, CRISPR/Cpf1mediated DNA-free plant genome editing, Nat. Commun. 8 (2017) 14406, http://dx.doi.org/10.1038/ncomms14406.

[58] X. Tang, L.G. Lowder, T. Zhang, A.A. Malzahn, X. Zheng, D.F. Voytas, Z. Zhong Y. Chen, Q. Ren, Q. Li, E.R. Kirkland, Y. Zhang, Y. Qi, A CRISPR-Cpf1 system for efficient genome editing and transcriptional repression in plants, Nat. Plants. 3 (2017) 17018, http://dx.doi.org/10.1038/nplants.2017.18.

[59] A. Endo, M. Masafumi, H. Kaya, S. Toki, Efficient targeted mutagenesis of rice and tobacco genomes using Cpf1 from Francisella novicida, Sci. Rep. 6 (2016) 38169, http://dx.doi.org/10.1038/srep38169.

[60] F. Gao, X.Z. Shen, F. Jiang, Y. Wu, C. Han, DNA-guided genome editing using the Natronobacterium gregoryi Argonaute, Nat. Biotechnol. 34 (2016) 768773, http://dx.doi.org/10.1038/nbt.3547.

[61] L. Wang, L. Wang, Q. Tan, Q. Fan, H. Zhu, Z. Hong, Z. Zhang, D. Duanmu, Efficient inactivation of symbiotic nitrogen fixation related genes in Lotus japonicus Using CRISPR-Cas9, Front. Plant Sci. 7 (2016) 1333, http://dx.doi org/10.3389/fpls.2016.01333.

[62] L. Yan, S. Wei, Y. Wu, R. Hu, H. Li, W. Yang, Q. Xie, High-efficiency genome editing in arabidopsis using YAO promoter-driven CRISPR/Cas9 system, Mol Plant 8 (2015) 1820-1823, http://dx.doi.org/10.1016/j.molp.2015.10.004.

[63] Y. Mao, Z. Zhang, Z. Feng, P. Wei, H. Zhang, J.R. Botella, J.-K. Zhu, Development of germ-line-specific CRISPR-Cas9 systems to improve the production of heritable gene modifications in Arabidopsis, Plant Biotechnol. J. 14 (2016) 519-532, http://dx.doi.org/10.1111/pbi.12468.

[64] S. Schiml, H. Puchta, Revolutionizing plant biology: multiple ways of genome engineering by CRISPR/Cas, Plant Methods 12 (2016) 8, http://dx.doi.org/ 10.1186/s13007-016-0103-0.

[65] V.T. Chu, T. Weber, B. Wefers, W. Wurst, S. Sander, K. Rajewsky, R. Kühn, Increasing the efficiency of homology-directed repair for CRISPR-Cas9induced precise gene editing in mammalian cells, Nat. Biotechnol. 33 (2015) 543-548, http://dx.doi.org/10.1038/nbt.3198.

[66] T. Sakuma, S. Nakade, Y. Sakane, K.-I.T. Suzuki, T. Yamamoto, MMEJ-assisted gene knock-in using TALENs and CRISPR-Cas9 with the PITCh systems, Nat. Protoc. 11 (2015) 118-133, http://dx.doi.org/10.1038/nprot.2015.140.

[67] Y. Sun, X. Zhang, C. Wu, Y. He, Y. Ma, H. Hou, X. Guo, W. Du, Y. Zhao, L. Xia Engineering herbicide-resistant rice plants through CRISPR/Cas9-mediated homologous recombination of acetolactate synthase, Mol. Plant 9 (2016) 628-631, http://dx.doi.org/10.1016/j.molp.2016.01.001.

[68] N.M. Butler, P.A. Atkins, D.F. Voytas, D.S. Douches, Generation and inheritance of targeted mutations in potato (Solanum tuberosum L.) using the CRISPR/Cas system, PLoS One 10 (2015) e0144591, http://dx.doi.org/10.1371/journal. pone.0144591.

[69] W. Li, F. Teng, T. Li, Q. Zhou, Simultaneous generation and germline transmission of multiple gene mutations in rat using CRISPR-Cas systems, Nat. Biotechnol. 31 (2013) 684-686, http://dx.doi.org/10.1038/nbt.2652.

[70] C.D. Richardson, G.J. Ray, M.A. DeWitt, G.L. Curie, J.E. Corn, Enhancing homology-directed genome editing by catalytically active and inactive CRISPR-Cas9 using asymmetric donor DNA, Nat. Biotechnol. 34 (2016) 339344, http://dx.doi.org/10.1038/nbt.3481.

[71] X. Liang, J. Potter, S. Kumar, N. Ravinder, J.D. Chesnut, Enhanced CRISPR/Cas9mediated precise genome editing by improved design and delivery of gRNA Cas9 nuclease, and donor DNA, J. Biotechnol. 241 (2017) 136-146, http://dx. doi.org/10.1016/j.jbiotec.2016.11.011.

[72] J.-B. Renaud, C. Boix, M. Charpentier, A. De Cian, J. Cochennec, E. Duvernois Berthet, L. Perrouault, L. Tesson, J. Edouard, R. Thinard, Y. Cherifi, S. Menoret S. Fontanière, N. de Crozé, A. Fraichard, F. Sohm, I. Anegon, J.-P. Concordet, C. Giovannangeli, Improved genome editing efficiency and flexibility using modified oligonucleotides with TALEN and CRISPR-Cas9 nucleases, Cell Rep. 14 (2016) 2263-2272, http://dx.doi.org/10.1016/j.celrep.2016.02.018.

[73] Y. Zhang, Z. Liang, Y. Zong, Y. Wang, J. Liu, K. Chen, J.-L. Qiu, C. Gao, Efficient and transgene-free genome editing in wheat through transient expression of CRISPR/Cas9 DNA or RNA, Nat. Commun. 7 (2016) 12617. doi:10.1038/ ncomms12617.

[74] J.W. Woo, J. Kim, S. Il Kwon, C. Corvalán, S.W. Cho, H. Kim, S.-G. Kim, S.-T. Kim S. Choe, J. Kim, DNA-free genome editing in plants with preassembled CRISPR-Cas9 ribonucleoproteins, Nat. Biotechnol. 33 (2015) 1162-1164, http://dx.doi.org/10.1038/nbt.3389.

[75] S. Svitashev, C. Schwartz, B. Lenderts, J.K. Young, A. Mark Cigan, Genome editing in maize directed by CRISPR-Cas9 ribonucleoprotein complexes, Nat Commun. 7 (2016) 13274, http://dx.doi.org/10.1038/ncomms13274.

[76] S. Subburaj, S.J. Chung, C. Lee, S.-M. Ryu, D.H. Kim, J.-S. Kim, S. Bae, G.-J. Lee Site-directed mutagenesis in Petunia $\times$ hybrida protoplast system using direct delivery of purified recombinant Cas9 ribonucleoproteins, Plant Cell Rep. 35 (2016) 1535-1544, http://dx.doi.org/10.1007/s00299-016-1937-7.

[77] C. Engler, R. Kandzia, S. Marillonnet, A one pot, one step, precision cloning method with high throughput capability, PLoS One 3 (2008), http://dx.doi. org/10.1371/journal.pone.0003647.

[78] D.G. Gibson, L. Young, R.-Y. Chuang, J.C. Venter, C.A. Hutchison, H.O. Smith Enzymatic assembly of DNA molecules up to several hundred kilobases, Nat Methods 6 (2009) 343-345, http://dx.doi.org/10.1038/nmeth.1318.

[79] G. Liang, H. Zhang, D. Lou, D. Yu, Selection of highly efficient sgRNAs for CRISPR/Cas9-based plant genome editing, Sci. Rep. 6 (2016) 21451, http://dx doi.org/10.1038/srep21451.

[80] J. Vad-Nielsen, L. Lin, L. Bolund, A.L. Nielsen, Y. Luo, Golden gate assembly of CRISPR gRNA expression array for simultaneously targeting multiple genes, Cell. Mol. Life Sci. 73 (2016) 4315-4325, http://dx.doi.org/10.1007/s00018 016-2271-5.

[81] M. Vazquez-Vilar, J.M. Bernabé-Orts, A. Fernandez-del-Carmen, P. Ziarsolo, J Blanca, A. Granell, D. Orzaez, A modular toolbox for gRNA-Cas9 genome engineering in plants based on the GoldenBraid standard, Plant Methods 12 (2016) 10, http://dx.doi.org/10.1186/s13007-016-0101-2. 
[82] G. Parry, N. Patron, R. Bastow, C. Matthewman, Meeting report: GARNet OpenPlant CRISPR-Cas workshop, Plant Methods. 12 (2016) 6, http://dx.doi. org/10.1186/s13007-016-0104-Z.

[83] L.G. Lowder, D. Zhang, N.J. Baltes, J.W. Paul, X. Tang, X. Zheng, D.F. Voytas, T.F. Hsieh, Y. Zhang, Y. Qi, A CRISPR/Cas9 toolbox for multiplexed plant genome editing and transcriptional regulation, Plant Physiol. 169 (2015) 971-985, http://dx.doi.org/10.1104/pp.15.00636.

[84] X. Tang, X. Zheng, Y. Qi, D. Zhang, Y. Cheng, A. Tang, D.F. Voytas, Y. Zhang, A single transcript CRISPR-Cas9 system for efficient genome editing in plants, Mol. Plant 9 (2016) 1088-1091, http://dx.doi.org/10.1016/j.molp. 2016.05.001.

[85] K. Xie, B. Minkenberg, Y. Yang, Boosting CRISPR/Cas9 multiplex editing capability with the endogenous tRNA-processing system, Proc. Natl. Acad. Sci. U.S.A. 112 (2015) 3570-3575, http://dx.doi.org/10.1073/pnas.1420294112.

[86] W. Wang, A. Akhunova, S. Chao, E. Akhunov, Optimizing multiplex CRISPR/ CAS9Cas9 system for wheat genome editing, Submitted. (2016). doi:10.1101/ 051342.

[87] L. Nissim, S.D. Perli, A. Fridkin, P. Perez-Pinera, T.K. Lu, Multiplexed and programmable regulation of gene networks with an integrated RNA and CRISPR/Cas toolkit in human cells, Mol. Cell 54 (2014) 698-710, http://dx.doi. org/10.1016/j.molcel.2014.04.022.

[88] Y. Osakabe, T. Watanabe, S.S. Sugano, R. Ueta, R. Ishihara, K. Shinozaki, K. Osakabe, Optimization of CRISPR/Cas9 genome editing to modify abiotic stress responses in plants, Sci. Rep. 6 (2016) 26685, http://dx.doi.org/ $10.1038 /$ srep26685.

[89] N.J. Baltes, A.W. Hummel, E. Konecna, R Cegan, A.N. Bruns, D.M. Bisaro, D.F. Voytas, Conferring resistance to geminiviruses with the CRISPR-Cas prokaryotic immune system, Nat. Plants 1 (2015) 15145, http://dx.doi.org/ 10.1038/nplants.2015.145

[90] K. Yin, T. Han, G. Liu, T. Chen, Y. Wang, A.Y.L. Yu, Y. Liu, A geminivirus-based guide RNA delivery system for CRISPR/Cas9 mediated plant genome editing, Sci. Rep. 5 (2015) 14926, http://dx.doi.org/10.1038/srep14926.

[91] J.S. Larsen, W.R. Curtis, RNA viral vectors for improved Agrobacterium mediated transient expression of heterologous proteins in Nicotiana benthamiana cell suspensions and hairy roots, BMC Biotechnol. 12 (2012) $1-11$.

[92] Y. Alagoz, T. Gurkok, B. Zhang, T. Unver, Manipulating the biosynthesis of bioactive compound alkaloids for next-generation metabolic engineering in opium poppy using CRISPR-Cas 9 genome editing technology, Nat. Publ. Gr (2016) 1-9, http://dx.doi.org/10.1038/srep30910.

[93] N.J. Baltes, J. Gil-Humanes, T. Cermak, P.A. Atkins, D.F. Voytas, DNA replicons for plant genome engineering, Plant Cell 26 (2014) 151-163, http://dx.doi org/10.1105/tpc.113.119792.

[94] J. Gil-Humanes, Y. Wang, Z. Liang, Q. Shan, C.V. Ozuna, S. Sánchez-León, N.J. Baltes, C. Starker, F. Barro, C. Gao, D.F. Voytas, High-efficiency gene targeting in hexaploid wheat using DNA replicons and CRISPR/Cas9, Plant J. 89 (2017) 1251-1262, http://dx.doi.org/10.1111/tpj.13446.

[95] M. Malnoy, R. Viola, M. Jung, O. Koo, S. Kim, J. Kim, R. Velasco, C.N. Kanchiswamy, DNA-free genetically edited grapevine and apple protoplast using CRISPR/Cas9 ribonucleoproteins, Front. Plant Sci. 7 (2016) 1-9, http:/ dx.doi.org/10.3389/fpls.2016.01904.

[96] Z. Liang, K. Chen, T. Li, Y. Zhang, Y. Wang, Q. Zhao, J. Liu, H. Zhang, C. Liu, Y. Ran, C. Gao, ARTICLE Efficient DNA-free genome editing of bread wheat using CRISPR/Cas9 ribonucleoprotein complexes, Nat. Publ. Gr. 8 (2017) 1-5, http:// dx.doi.org/10.1038/ncomms14261.

[97] D. Burstein, L.B. Harrington, S.C. Strutt, A.J. Probst, K. Anantharaman, B.C Thomas, J.A. Doudna, J.F. Banfield, New CRISPR-Cas systems from uncultivated microbes, Nature (2016) 1-20, http://dx.doi.org/10.1038 nature21059.

[98] A.J. Pierce, Ku DNA end-binding protein modulates homologous repair of double-strand breaks in mammalian cells, Genes Dev. 15 (2001) 3237-3242, http://dx.doi.org/10.1101/gad.946401.

[99] F. Delacôte, M. Han, T.D. Stamato, M. Jasin, B.S. Lopez, An xrcc4 defect or Wortmannin stimulates homologous recombination specifically induced by double-strand breaks in mammalian cells, Nucleic Acids Res. 30 (2002) 3454 3463, http://dx.doi.org/10.1093/nar/gkf452.

[100] Y. Qi, Y. Zhang, F. Zhang, J.A. Baller, S.C. Cleland, Y. Ryu, C.G. Starker, D.F Voytas, Increasing frequencies of site-specific mutagenesis and gene targeting in Arabidopsis by manipulating DNA repair pathways, Genome Res. 23 (2013) 547-554, http://dx.doi.org/10.1101/gr.145557.112.

[101] T. Gutschner, M. Haemmerle, G. Genovese, G.F. Draetta, L. Chin, Posttranslational regulation of Cas9 during G1 enhances homology-directed repair, Cell Rep. 14 (2016) 1555-1566, http://dx.doi.org/10.1016/j.celrep. 2016.01.019.
[102] S.E. Howden, B. McColl, A. Glaser, J. Vadolas, S. Petrou, M.H. Little, A.G. Elefanty, E.G. Stanley, A Cas9 variant for efficient generation of indel-free knockin or gene-corrected human pluripotent stem cells, Stem Cell Rep. 7 (2016) 508-517, http://dx.doi.org/10.1016/j.stemcr.2016.07.001.

[103] Y. Saintigny, F. Delacôte, D. Boucher, D. Averbeck, B.S. Lopez, XRCC4 in G1 suppresses homologous recombination in S/G2, in G1 checkpoint-defective cells, Oncogene 26 (2007) 2769-2780, http://dx.doi.org/10.1038/sj. onc. 1210075 .

[104] N. Saleh-Gohari, T. Helleday, Conservative homologous recombination preferentially repairs DNA double-strand breaks in the S phase of the cell cycle in human cells, Nucleic Acids Res. 32 (2004) 3683-3688, http://dx.doi. org/10.1093/nar/gkh703.

[105] T. Maruyama, S.K. Dougan, M.C. Truttmann, A.M. Bilate, J.R. Ingram, H.L. Ploegh, Increasing the efficiency of precise genome editing with CRISPR-Cas9 by inhibition of nonhomologous end joining, Nat. Biotechnol. 33 (2015) 538542, http://dx.doi.org/10.1038/nbt.3190.

[106] J. Song, D. Yang, J. Xu, T. Zhu, Y.E. Chen, J. Zhang, RS-1 enhances CRISPR/Cas9and TALEN-mediated knock-in efficiency, Nat. Commun. 7 (2016) 10548, http://dx.doi.org/10.1038/ncomms10548.

[107] C. Yu, Y. Liu, T. Ma, K. Liu, S. Xu, Y. Zhang, H. Liu, M. La Russa, M. Xie, S. Ding, L. S. Qi, Small molecules enhance CRISPR genome editing in pluripotent stem cells, Cell Stem Cell 16 (2015) 142-147, http://dx.doi.org/10.1016/j. stem.2015.01.003.

[108] M. Hanin, J. Paszkowski, Plant genome modification by homologous recombination, Curr. Opin. Plant Biol. 6 (2003) 157-162. http://www.ncbi. nlm.nih.gov/pubmed/12667873.

[109] D.G. Schaefer, A new moss genetics: targeted mutagenesis in Physcomitrella patens, Annu. Rev. Plant Biol. 53 (2002) 477-501, http://dx.doi.org/10.1146/ annurev.arplant.53.100301.135202.

[110] M. Lopez-Obando, B. Hoffmann, C. Géry, A. Guyon-Debast, E. Téoulé, C. Rameau, S. Bonhomme, F. Nogué, Simple and efficient targeting of multiple genes through CRISPR-Cas9 in Physcomitrella patens, G3 (Bethesda). (2016) 127. doi: $10.1534 / \mathrm{g} 3.116 .033266$.

[111] B. Trouiller, D.G. Schaefer, F. Charlot, F. Nogué, MSH2 is essential for the preservation of genome integrity and prevents homeologous recombination in the moss Physcomitrella patens, Nucleic Acids Res. 34 (2006) 232-242. http://dx.doi.org/10.1093/nar/gkj423.

[112] Y. Kamisugi, D.G. Schaefer, J. Kozak, F. Charlot, N. Vrielynck, M. Holá, K.J. Angelis, A.C. Cuming, F. Nogué, MRE11 and RAD50, but not NBS1, are essential for gene targeting in the moss Physcomitrella patens, Nucleic Acids Res. 40 (2012) 3496-3510, http://dx.doi.org/10.1093/nar/gkr1272.

[113] D.G. Schaefer, F. Delacote, F. Charlot, N. Vrielynck, A. Guyon-Debast, S. Le Guin, J.M. Neuhaus, M.P. Doutriaux, F. Nogué, RAD51 loss of function abolishes gene targeting and de-represses illegitimate integration in the moss Physcomitrella patens, DNA Repair (Amst) 9 (2010) 526-533, http://dx. doi.org/10.1016/j.dnarep.2010.02.001.

[114] B. Trouiller, F. Charlot, S. Choinard, D.G. Schaefer, F. Nogué, Comparison of gene targeting efficiencies in two mosses suggests that it is a conserved feature of Bryophyte transformation, Biotechnol. Lett. 29 (2007) 1591-1598, http://dx.doi.org/10.1007/s10529-007-9423-5.

[115] H. Puchta, F. Fauser, Gene targeting in plants: 25 years later, Int. J. Dev. Biol. 57 (2013) 629-637, http://dx.doi.org/10.1387/ijdb.130194hp.

[116] Y. Kamisugi, K. Schlink, S.A. Rensing, G. Schween, M. von Stackelberg, A.C. Cuming, R. Reski, D.J. Cove, The mechanism of gene targeting in Physcomitrella patens: homologous recombination, concatenation and multiple integration, Nucleic Acids Res. 34 (2006) 6205-6214, http://dx.doi. org/10.1093/nar/gkl832.

[117] D.G. Schaefer, J.P. Zrÿd, Efficient gene targeting in the moss Physcomitrella patens, Plant J. 11 (1997) 1195-1206. http://www.ncbi.nlm.nih.gov/ pubmed/9225463.

[118] F. Charlot, L. Chelysheva, Y. Kamisugi, N. Vrielynck, A. Guyon, A. Epert, S. Le Guin, D.G. Schaefer, A.C. Cuming, M. Grelon, F. Nogué, RAD51B plays an essential role during somatic and meiotic recombination in Physcomitrella, Nucleic Acids Res. 42 (2014) 11965-11978, http://dx.doi.org/10.1093/nar/ gku890.

[119] E. Waltz, CRISPR-edited crops free to enter market, skip regulation, Nat. Biotechnol. 34 (2016), http://dx.doi.org/10.1038/nbt0616-582. 582-582.

[120] P. Mali, L. Yang, K.M. Esvelt, J. Aach, M. Guell, J.E. DiCarlo, J.E. Norville, G.M Church, RNA-guided human genome engineering via Cas9, Science 339 (2013) 823-826, http://dx.doi.org/10.1126/science.1232033.

[121] N.W. Ashton, D.J. Cove, The isolation and preliminary characterisation of auxotrophic and analogue resistant mutants of the moss, Physcomitrella patens, Mol. Gen. Genet. MGG. 154 (1977) 87-95, http://dx.doi.org/10.1007/ BF00265581. 